\title{
Recent Canadian Evidence on Job Quality by Firm Size
}

\author{
by
}

\author{
Marie Drolet* and René Morissette**
}

\author{
No. 128 \\ 11F0019MPE No. 128 \\ ISSN: $1200-5223$ \\ ISBN: 0-660-17667-X \\ Price: $\$ 5.00$ per issue, $\$ 25.00$ annually \\ Business and Labour Market Analysis \\ 24, R.H. Coats Building, Ottawa, K1A 0T6 \\ *Statistics Canada (613) 951-5691 \\ **Statistics Canada (613) 951-3608 \\ Facsimile Number: (613) 951-5403 \\ E-mail: drolmar@statcan.ca \\ moriren@statcan.ca
}

November 1998

This paper represents the views of the author and does not necessarily reflect the opinions of Statistics Canada. 



\section{Table of Contents}

I. Introduction 1

II. The Data

III. Changes in job quality over time, 1986 - 1997 3

III.1. The wage gap between small and large firms, 1986-1997. 3

III.2. The gap in pension coverage 5

IV. How do work schedules vary across employer size groups? 6

IV.1. The length of the work week 6

IV.1.A Total hours usually worked per week 6

IV.1.B Usual paid hours on a regular basis 7

IV.1.C. Distribution of weekly hours by firm size 8

IV.2 Hours per day and days per week 8

IV.3 The timing of work 10

V. Does shiftwork explain the employer size wage premium? 11

VI. Summary and Conclusions 12

Bibliography 39 



\section{Abstract}

We provide recent evidence on job characteristics by firm size in Canada. Using a variety of household surveys, we assemble a wide set of facts on wages, fringe benefits and work schedules in small and large firms. We show that the wage gap between small and large firms has remained fairly stable over the past decade. After controlling for observable worker characteristics and industry-specific effects, large firms pay $15-20 \%$ more than small firms. Pension plan coverage remains at least four times higher in large firms than in small firms. While the gap in pension coverage between small and large firms has not increased over time for men, there is some evidence that it has increased for women. We assess the extent to which work schedules vary between small and large firms. Our results indicate that compared to workers in large firms, employees of small firms work at least as many weekly hours. Furthermore, they are more likely to work more than five days per week. This implies that the firm size wage premium cannot be explained by a longer workweek in large firms. As long as workers prefer working during the day, the greater frequency of shift work in large, goods-producing companies is one dimension along which work schedules are less desirable in large firms. According to the theory of compensating differentials, the size-wage differential may partially reflect the willingness of large firms to compensate workers for shift work. We test this hypothesis and conclude that shift work has virtually no effect on the firm size wage premium. Our results emphasize the need to look at several dimensions of work to assess how job quality varies between small and large firms.

Key words: Firm size; Wages; Job quality; Pension coverage; Work schedules. 



\section{Introduction}

The extent to which jobs in small firms differ from those in large firms is likely to be on the agenda of analysts and policy-makers for several reasons. First, following Birch (1981), a substantial empirical literature geared towards industrial policy has developed and has shown that net job creation is higher in small firms than in large firms (Davis, Haltiwanger and Schuh, 1993; Picot et al. 1994; Picot and Dupuy, 1996). Yet small employers pay lower wages for otherwise comparable workers (Brown and Medoff, 1989; Morissette, 1993). As a result, the relative success of small firms in creating new jobs is reduced significantly when the new jobs created are weighted by employer size-specific wages (Baldwin, 1996). Furthermore, the wage gap between small and large manufacturing plants has risen substantially between the seventies and the mid-eighties (Davis and Haltiwanger, 1991; Baldwin, 1996).

Second, the fact that small employers pay lower wages raises interesting questions about the wage determination process. As suggested by efficiency wage models (Bulow and Summers, 1986) the size-wage differential may reflect differences in employer characteristics rather than differences in workers' unobserved abilities (Evans and Leighton, 1989; Idson and Feaster, 1990) or compensating differentials. If so, luck - i.e. the opportunity of being hired by a large firm - may be a major determinant of a worker's rank in the earnings distribution. This latter effect is further compounded by the fact that large firms also offer better pension coverage (Morissette, 1993; Even and MacPherson, 1996). Given the important changes observed over the last twenty years in the wage structure of most OECD countries - namely, the decline of the real wages of low-skilled workers and of young workers - firm size remains an important determinant of an individual's position in the wage distribution.

Third, the Canadian unemployment rate has hovered around 9\% since the 1990-92 recession and while the probability of being permanently laid-off has not increased in the nineties - compared to the eighties - the hiring rate has dropped significantly (Picot and Lin, 1997). In an economy where it is harder to find a new job after losing a job, Canadians are likely to be concerned about the quality of jobs produced by the economy. As noted above, employer size is one obvious dimension across which job quality is likely to vary.

These reasons highlight the need to provide recent Canadian evidence on job quality in large and small firms.

The goal of this paper is twofold. First, we explore changes in job quality over time by reexamining the extent to which large firms pay higher wages and offer more fringe benefits than small firms. Second, we document how work schedules vary across employer size groups and we investigate the size-wage differential attributable to variations in the length and in the timing of work by employer size groups.

The plan of the paper is as follows. In Section II, we present the data used in the paper and document the evolution of employment across firm sizes since the mid-eighties. Next, we examine changes in job quality over time by examining the employer size-wage premium (Section III.1.) and the differences in the degree to which fringe benefits are offered in small and large firms (Section III.2.). Work schedules in large and small firms are studied in Section IV. In Section V, we show that 
differences in work schedules cannot explain the firm size-wage premium. A summary of the findings and concluding remarks follow (Section VI.).

\section{The Data}

In this paper, we define firm size in terms of the number of paid workers employed at all Canadian locations owned by a given employer. Small firms are defined as having less than 20 employees, medium-sized employers employ between 20 and 499 workers, and large firms have 500 or more workers. We use a wide variety of household surveys to compare job characteristics in large and small firms. The various data sets used in the paper are described in Appendix 1.

Unless otherwise specified, the sample used in this paper consists of paid workers aged 17 to 64, who are not full-time students and who are employed in the commercial sector. Self-employed individuals as well as employees working in agriculture, fishing and trapping, education and related services, health and welfare services, religious organizations, federal, provincial and local administration and other government offices are excluded.

\section{Distribution of Employment by Employer Size Class}

In Table 1, we present the distribution of employment by firm size. The first panel shows data from the Longitudinal Employment Analysis Program (LEAP) file of Statistics Canada. The period covered is 1983-1993. The numbers show that the relative importance of large firms in total employment decreased during the period: large companies accounted for $41 \%$ of employment in the commercial sector in 1983, compared to $37 \%$ in 1993. The decline in large firms' share of employment was associated mainly with an increase in the relative importance of medium-sized companies. These companies saw their share of employment rise from 32\% in 1983 to 35\% in 1993. The relative importance of small firms rose 1 percentage point during the period.

In the second panel of Table 1, we show the distribution of employment by firm size derived from various household surveys. Because non-response rates on firm size vary substantially across household surveys we restrict our attention to jobs for which firm size is known. ${ }^{1}$ Overall, the numbers show greater variability than those derived from LEAP. In particular, the decline in the relative importance of large firms is not evident in these data. However, the share of employment in each size category is comparable to those observed in LEAP. ${ }^{2}$

\footnotetext{
1 The non-response rates on firm size for the various surveys are: Labour Market Activity Survey (LMAS) $11-16 \%$; Survey of Labour and Income Dynamics (SLID) 2 - 3\%; and Labour Force Survey (LFS) 3\%.

2 See Appendix 2 for information on the distribution of employment by establishment size.
} 


\section{Changes in Job Quality Over Time, 1986 - 1997}

\section{III.1. The Wage Gap Between Small and Large Firms, 1986-1997}

Recent work by Davis and Haltiwanger (1991) in the United States and Baldwin (1996) in Canada has shown that the wage gap between small and large manufacturing plants has risen substantially between the seventies and the mid-eighties. Baldwin (1996) uses data from the Census of Manufactures and examines the size-wage differential throughout the 1973-1991 period. He divides the manufacturing sector into five groups (resource-intensive, labour-intensive, scale-based, product-differentiated and science-based) and finds that in all these groups, the wage gap between plants with less than 100 employees and those with 500 employees or more has risen between 1973 and 1986. However, for all industrial groups except product-differentiated, the wage gap has either stabilized or slightly narrowed between 1986 and 1991. As a result, the plant size wage differential did not increase further between 1986 and 1991 for the manufacturing sector as a whole. Even though these findings are restricted to the manufacturing sector ${ }^{4}$, they raise the following question: what happened to the employer size wage differential between 1986 and 1997 ?

Table 2 shows the average hourly wages by firm size for all paid workers employed in full-time jobs. ${ }^{5}$ We restrict our attention to full-time jobs because the sample size for part-time jobs is relatively small for a multivariate analysis. ${ }^{6}$ The numbers are presented for the 1986-1997 period for men and women separately. The raw data shows that hourly wages rise monotonically with firm size for both men and women. Men employed in large firms earned 39\% to $46 \%$ more than their counterparts in small firms. For women, the year 1986 appears as an outlier: the wage gap between large and small firms amounts to $55 \%$ in 1986 while it varies between $35 \%$ and $42 \%$ during subsequent years ${ }^{7}$. Excluding 1986 from the analysis, there is no evidence that the firm size wage premium has changed over the last decade for both men and women.

Has the firm size wage premium changed over the last decade? To test this hypothesis, we run gender-specific wage equations for each year. As is commonplace in labour economics, the dependent variable is the natural logarithm of hourly wages. Our set of controls include an intercept term, age, age squared, marital status, union status, industry (2-digit level), province and four dummy variables for firm size. ${ }^{8}$ Controls for occupation (2-digit level) are omitted in the first

\footnotetext{
3 See Appendix 1 for a description of hourly wage rate calculations in LMAS, SLID, and LFS.

4 Note that these results do not take into account possible changes over time in the quality of the workforce between small and large plants.

5 Appendix 3 shows the wage gap between small and large establishments for the 1986 - 1997 period.

6 We also restrict our analysis to jobs for which firm size is known.

7 Inspection of the distribution of wages for each year reveals an unusually large number of women earning between $\$ 2$ and $\$ 4$ per hour in 1986. We have no good explanation for this anomaly.

8 Education is excluded from our wage equations because the categories used to define educational levels differ between the 1986-1988 and the 1989-1997 period (Gower, 1993). Tenure is also excluded from our wage equation since the calculation of job seniority differs among the various surveys. Morissette (1993b) compares the number of job starts from the longitudinal version of the LMAS 1988-1990 to the number of job starts from administrative data and shows that the LMAS overestimates the number of jobs started in 1988 compared to 1989. While the reason for this overestimation is unclear, it has obvious
} 
specification and are included in the second. We show the firm size coefficients from the genderspecific wage equations in Table 3.

For men, the second model indicates that the net wage differential between large and small firms reaches a minimum of $19.8 \%$ in 1994 and a maximum of $26.5 \%$ in $1989 .{ }^{9}$ This is consistent with our earlier findings (Morissette, 1993). When we plot the net wage differentials obtained from both models, no trend appears (Chart 1). This confirms the hypothesis suggested by Table 2: there is no evidence that the wage gap between small and large firms has changed over the last ten years.

The same story applies to women. The net wage differential estimated from the second model is roughly 20\% between 1987 and 1990, displays a U-shape between 1990 and 1994 and is 18\% in 1997. Most importantly, inspection of Chart 1 shows that the firm size wage premium has not increased between 1987 and 1997 for women.

In Appendix 3, we replicate Tables 2 and 3 and examine the wage differential by establishment size. Our multivariate analysis shows, once again, that the wage gap between the smallest and largest size category has not increased between 1986 and 1997 (Chart 2). ${ }^{10} 11$

Combined with previous work from Baldwin (1996), our results indicate that the wage gap between small and large employers has remained fairly stable in Canada over the last decade after rising - at least in the manufacturing sector - between the 1970s and the mid-1980s. As long as the size-wage differential has also risen between the 1970s and the mid-1980s in the services sector ${ }^{12}$, this implies that whatever factors caused the size-wage differential to increase during that period either are no longer at play or are offset by other forces. For instance, if, as argued by Davis and Haltiwanger (1991), skill-biased technological changes drove the increase in the size-wage premium, then this suggests that increases in the relative demand for highly skilled workers either have stopped or have been accompanied by corresponding increases in the relative supply of such workers. The fast growth in the number of Canadian university graduates since the beginning of the nineties could be consistent with the latter view.

implications for the tenure variable: jobs which may have started prior to 1988 but are reported as having started in 1988 will lead to a downward bias in the tenure variable.

9 The percentage wage differential between large and small firms equals the anti-log of the regression coefficient minus 1 . For instance, the regression coefficient reaches a minimum of 0.181 in 1994 , implying a wage differential of $19.8 \%$, i.e. $\exp (0.181)$ -1 .

${ }^{10}$ We also present average hourly wages by establishment size for the manufacturing sector as a whole (Appendix 3, Table A-3). We find no evidence of a widening wage gap between 1986 and 1997.

${ }^{11}$ To test whether the employer size-wage premium has changed over time, we regressed the net wage differentials obtained from both models on a constant and a time trend. For firm size, the time trend is never significant at the 5\% level, whatever model is used and whatever gender is considered. For establishment size, using the net wage differentials obtained from the first model, the time trend is significant at the 5\% level for men and women. This suggests an increase in the establishment size wage differential of about 0.5 percentage point per year (or 5 percentage points over a ten-year period). However, it becomes insignificant when using the net wage differentials obtained from the second model, in which controls for occupation are included.

12 There is no Canadian data which allows us to check whether the size-wage differential has increased in the services sector between the 1970s and the mid-1980s. 
The reason(s) why large firms pay higher wages than small firms still remains a puzzle for labour economists. One argument often used to explain the aforementioned wage differences relies on efficiency wage models: it may be profitable for large firms to pay higher wages in order to increase worker effort (Shapiro and Stiglitz, 1984, Akerlof 1982) or to reduce worker turnover (Salop, 1979). In these models, workers' unobserved skills are assumed to be the same in both small and large firms. An alternative explanation is that workers in large firms have more unobserved abilities than employees in small companies and consequently, the firm size wage premium would simply (partly) reflect differences in worker quality. ${ }^{13}$ A third argument often heard is that large firms pay higher wages because they are more capital-intensive and therefore have more productive workers. This argument however, is not sufficient in itself to explain the wage-firm size relationship. Although higher productivity allows firms to pay higher wages, it does not force firms to do so. One still has to explain why large firms would find it profitable to pay higher wages.

\section{III.2. The Gap in Pension Coverage ${ }^{14}$}

The fact that the wage gap between small and large employers has shown little change over the last ten years is not sufficient to conclude that the monetary rewards to working in large firms have stayed constant relative to those in small firms. The proportion of workers covered by pension plan as well as the generosity of these pension plans may have changed across employer sizes over time. Since there is no nationwide survey measuring the generosity of pension plans, we limit our analysis to the incidence of pension plan coverage.

In Table 4, we show pension plan coverage by firm size for the 1986-1995 period. Throughout the period, roughly half of male workers had a pension plan connected with their job. Women are less likely to have a pension plan, owing partly to their overrepresentation in small firms, in part-time jobs and in low-paid jobs of the consumer services sector. Nevertheless, their coverage rose a total of three percentage points throughout the period. ${ }^{15}$ For all years, pension coverage increases monotonically with firm size. ${ }^{16}$ Pension coverage is at least four times higher in large firms than in small firms. For instance, in 1995, 13\% of men in small firms and 74\% of men in large firms were covered by a pension plan. The corresponding numbers for women are $6 \%$ and $53 \%$.

\footnotetext{
${ }^{13}$ One way to account for this argument is to use longitudinal data to estimate the wage changes workers experience when they move from one employer to another. In previous work (Morissette, 1992), we used data from the longitudinal version of LMAS 1986-87 to perform this exercise: we estimated fixed-effects models and found that after controlling for workers' constant-over-time unobserved abilities, the wage gap between large and small firms was $9 \%$.

${ }^{14}$ The data used in this section is taken from the Labour Market Activity Survey (LMAS) and the Survey of Labour and Income Dynamics (SLID). The Labour Force Survey does not have data on pension coverage. The numbers are presented for all jobs held by paid workers in the commercial sector and who are not full-time students.

15 The careful reader will note that in Table 4, the pension coverage for women in 1995 is close to its 1986 level. This unexpected decline is partly due to sampling variability. The increase in women's coverage for the 1986-1994 period is consistent with the findings of administrative data on pension coverage.

${ }^{16}$ Even and MacPherson (1996) identify two explanations for why pension coverage rates rise with employer size. The first explanation is that larger employers may have greater hiring and training costs and may use pension plans as a tool to defer compensation and therefore reduce labour turnover. The second explanation is that larger firms benefit from economies of scale in the administration of pension plans.
} 
For men, the gap in pension coverage between small and large firms varies between 58 and 61 percentage points during the period but shows no trend. For women, the gap rises from 47 percentage points in 1986 to 56 percentage points in 1993 and then falls back to 47 percentage points in 1995. More generally, women's coverage has stagnated in small firms but has increased in large firms, at least until 1995. If most of the change observed between 1993 and 1995 reflects sampling variability, then these results may indicate that the gap in pension coverage between small and large firms has widened for women over the last decade. Given the high variability of the numbers between 1993 and 1995, this finding is best viewed as preliminary. Hence, while the gap in pension coverage has not increased for men, there is some evidence that it may have increased for women.

Other fringe benefits such as medical/health insurance, dental plan, vacation leave and sick leave are also considerably more frequent in large firms than in small firms (Table 5).

Although wages and fringe benefits are meaningful symbols of job quality, other components of the job matter. Next, we assess the extent to which work schedules vary between small and large firms.

\section{How Do Work Schedules Vary Across Employer Size Groups?}

In the previous section, we established that large firms pay higher wages to comparable workers, are more likely to offer pension plans than small firms and that - except for the possible widening of the gap in pension coverage for women - these stylized facts have not changed significantly since the mid-eighties. Even though wages and fringe benefits are important indicators of job quality, they do not cover all components of a job. The number of hours worked and the timing of these work hours also matter. Large firms could pay higher wages to compensate workers for undesirable work schedules such as long weekly hours, long work days, or shift work. Using data from the Survey of Work Arrangements of 1995, we examine the extent to which these hypotheses are valid by documenting how work schedules vary across employer size.

\section{IV.1. The Length of the Work Week}

\section{IV.1.A Total Hours Usually Worked per Week}

On average, male workers tend to work as many hours per week in small firms (40.7) as they do in large firms (40.5) (Table 6, Panel I). In full-time jobs, male employees of small companies work longer hours (42.5) than those in large companies (41.3). However, the difference does not remain significant at the $5 \%$ level when we regress weekly hours on a detailed set of controls for industry and occupations (Table 6, Panel II). Similarly, results not reported here show no significant difference across firm sizes in part-time jobs.

In contrast, the length of women's workweek differs between small and large firms. Overall, women in small firms work an average of 32.4 hours per week while in large firms, the average workweek is 35.2 hours (Table 6, Panel I). This difference can be explained by two factors. First, female parttime work is much more frequent in small firms. Roughly one in three female workers in small 
firms and one in five female workers in large firms work less than 30 hours per week. Second, women employed part-time work on average fewer hours in small firms (17.2) than they do in large firms (19.5). This difference is attenuated yet remains statistically significant in multivariate analysis. ${ }^{17}$ Women employed full-time in small firms work virtually the same number of hours as those in large firms (Table 6, Panels I and II).

\section{IV.1.B Usual Paid Hours on a Regular Basis}

The similarity of total usual weekly hours by male workers in small and large firms hides interesting differences. The Survey of Work Arrangements allows us disaggregate total hours usually worked per week into (1) usual paid hours worked on a regular basis, (2) usual paid hours worked overtime and (3) usual unpaid hours.

For men, paid hours worked on a regular basis are longer in small firms (39.4 vs. 38.6, Table 7, Panel I) but paid overtime hours are longer in large firms (0.8 vs. 1.4$).{ }^{18}$ In other words, men in small firms seem to work longer hours before starting to work overtime and then work fewer hours overtime. Regression results confirm that using the concept of usual paid hours worked on a regular basis, males in small companies tend to work on average, roughly one more hour before overtime comes into play (Table 7, Panel II). ${ }^{19}$ The fact that the male workweek is longer in small firms coupled with longer paid overtime hours in large firms explains why the total usual hours worked per week is the same for men employed in either small or large firms.

The story outlined above for women remains when we use the concept of usual paid hours worked on a regular basis. Once again, the female workweek is shorter in small firms mainly because female part-time work is more frequent in small firms and also because women's part-time jobs involve much fewer hours in small firms than in large firms. Interestingly, women employed fulltime appear to work slightly more in small companies than in large ones (Table 7, Panel II).

Overall, the results of Tables 6 and 7 do not support the idea that the workweek is shorter in small firms. Full-time male and female employees work at least as many hours in small firms as they do in large firms (Table 8). Part-time male workers work the same number of hours in both small and large companies. The workweek is shorter in small firms only for women employed part-time. As a result, for $91 \%$ of the workforce, average weekly hours are not shorter in small firms. This implies

\footnotetext{
${ }^{17}$ Results not shown here indicate that, depending on the specification used, women employed part-time in small firms work 1.0 to 1.9 fewer hours than those employed part-time in large firms.

18 The rate at which overtime is paid in small and large firms may be examined using the Survey of Work Arrangements of 1995. Overtime is paid with money or a combination of money and time off in roughly $90 \%$ of the cases in both small and large firms. However, there are tremendous differences in the rate at which overtime is paid: $88 \%$ of men in large firms and $52 \%$ of men in small firms whose overtime is paid partly or only through money are paid time and a half or double time. The corresponding percentages for women are $69 \%$ and $26 \%$. Thus, the wage supplement received when working overtime is higher in large firms than it is in small firms.

${ }^{19}$ No significant difference in the length of the workweek between large and small firms is found for men employed part-time.
} 
that the size-wage differential documented in Section III.1 cannot be explained by differences in the number of workhours.

\section{IV.1.C. Distribution of Weekly Hours by Firm Size}

We also examined the distribution of weekly hours by firm size. At the aggregate level, the distribution of male weekly hours is more polarized in small firms than it is in large firms: more men work either short hours ( $<35$ hours) or long hours ( $>50$ hours) in small firms. The dispersion of female weekly hours is more heavily weighted towards short hours in small firms. To test whether the propensity to work short hours or long hours varies systematically by firm size, we ran logit models for the probability of working less than 35 hours and more than 50 hours, respectively. ${ }^{20}$ The results from the multivariate analysis indicate that the probability of working short hours does not differ by firm size for men but is greater in small firms for women. This suggests that for women, part-time work is more prevalent in small firms. In contrast, for both men and women, the probability of working long hours does not differ by firm size. This implies that the size-wage differential documented in Section III.1 cannot be explained by differences in the distribution of workhours.

\section{IV.2 Hours per Day and Days per Week}

Traditional models of labour supply and labour demand tend to combine daily work hours and number of workdays to examine weekly hours or even annual hours. This aggregation assumes that the number of workdays and daily hours behave identically in response to either employer shocks or in response to worker preferences towards their worktime. While the distinction between daily hours and workdays has not been emphasized in the empirical literature, it is easy to recognize its importance. Employers do not treat days and hours the same in their decision making process and it is unlikely that workers would be indifferent to changes in their daily hours or in their number of work days. ${ }^{21}$ According to Hamermesh (1996), the determinants of work time should distinguish between daily hours and number of work days. A corollary of this argument is that both employers and workers belonging to various employment size groups may treat workdays and daily hours differently.

Table 9 presents the distributions of daily hours and days worked per week jointly by firm size. The first three columns of each panel show the number of workdays for employees whose days do not vary while the first three rows show the number of daily hours for employees whose hours do not vary. The pair daily hours-workdays cannot be computed for employees with varying schedules. The relative importance of these workers is far from negligible. Both in small and large firms, individuals whose hours or days vary account for roughly $33 \%$ of all employees. ${ }^{22}$ Workers who have constant schedules represent the remaining two-thirds of the workforce.

\footnotetext{
20 The models were estimated separately for men and women and included, apart from worker characteristics and firm size, a set of industry controls at the 2-digit level.

${ }^{21}$ For a given number of weekly hours, say 40, individuals who work five days per week have possibilities of consuming leisure which differ from those whose workweek is distributed over six days.

${ }^{22}$ Individuals working on shifts or on irregular schedules represent the majority of these employees. They account for $71 \%$ of employees whose days vary and for $54 \%$ of employees whose hours vary.
} 
As expected, the distribution of daily hours and workdays is concentrated around the 7-8 hour and 5 -day schedules. Of all workers employed in small firms, roughly $40 \%$ have constant schedules of 7-8 hours per day and 5 days per week. The corresponding percentage is $52 \%$ in large firms. If one views such schedules as being "standard" - i.e. typical of North-American economies - this implies that standard schedules are less prevalent in small firms.

In an accounting sense, part of the difference is due to the fact that schedules with more than five days per week are much more frequent in small firms: $14 \%(10 \%)$ of men (women) employed in small companies compared to only $7 \%$ (4\%) for those in large companies work more than five days per week. The most obvious explanation for this difference is that small firms are over-represented in consumer services (i.e. retail trade, restaurants, hotels), a sector in which many individuals work six days. ${ }^{23}$ However, this is far from a complete explanation: in all other major industrial groups except manufacturing, the propensity to work more than five days is roughly twice as high in small firms as it is in large firms (Table 10).

A second element is the greater incidence of short workweeks among women in small firms. Sixteen percent of women employed in small firms work 1 to 4 days per week, compared to only $6 \%$ for those employed in large firms. This likely reflects the greater importance of part-time work among small employers.

Do these differences in work schedules truly capture size effects rather than variation in worker or job characteristics? To test this hypothesis, we estimate logit models for (1) the probability of having a constant schedule of 7-8 hours per day and 5 days per week, (2) the probability of working more than 5 days per week and (3) the probability of working less than 5 days per week. ${ }^{24}$ For women, all previous relationships hold in a multivariate setting: women in small firms are less likely to have a constant schedule of 7-8 hours per day and 5 days per week and are more likely to work either few days or several days (i.e. less than five days or more than five days, respectively). The probability of men having a "standard" schedule no longer varies between small and large firms. However, along with their female counterparts, men in small firms remain more likely to work several days (Table 11).

If workers view 6 day-schedules as less desirable than 5 day-schedules, one could argue - using the numbers presented in Tables 9-11 - that work schedules in small firms are inferior to those in large firms. A counter-argument is that, among women, short workweeks (in both daily hours and number of workdays) are significantly more frequent in small firms. The large number of part-time jobs held by female workers in small firms may respond to the needs of some women to balance family responsibilities and work (Blank, 1990). The fact that the proportion of women involuntarily

\footnotetext{
${ }^{23}$ Weiss (1996) suggests that the behaviour of some firms and workers may make it beneficial for others to schedule their activities differently from what would be their choice in vacuo: this may explain the 6-7-day workweek in retail trade, hotels and restaurants.

${ }^{24}$ The set of explanatory variables includes age, education, tenure, union status, firm size, industry (2-digit level) and occupation (1-digit level).
} 
employed part-time is not higher in small firms than it is in large firms is consistent with this view. ${ }^{25}$ Hence, the sole examination of the number of days worked does not yield a clear verdict as to whether work schedules are more or less desirable in small companies.

\section{IV.3 The Timing of Work}

Apart from weekly hours, daily hours and workdays, the time of the day during which work is performed also matters. ${ }^{26}$ Workers are unlikely to be indifferent between working at night and working during the day. Unsurprisingly, the majority of Canadians work a regular daytime shift. Yet those who have alternative work arrangements are far from negligible: almost $30 \%$ of paid workers work shifts (i.e. night, evening, rotating or split shifts), on-call or have casual or irregular schedules. $^{27}$

The timing of work differs drastically between the goods sector and the services sector: shift work is much more frequent in the goods sector. In the goods-producing sector, shift work is heavily concentrated in large firms: roughly $40 \%$ (17\%) of men (women) employed in large firms compared to $4 \%(4 \%)$ of those employed in small firms work shifts (Table 12). On the other hand, small firms use on-call, casual and irregular schedules at least three times more often than large companies. In the services sector, the work schedules of small and large employers are much more similar: this is especially true for women. Both in small and large firms, roughly $15 \%$ of men and women are oncall or on casual/irregular schedules.

If work schedules depend on the type of technology used, on firms' capital intensity and on business strategies, then the fact that work schedules in the goods sector differ widely by firm size suggests that technologies, capital-labour ratios and business strategies are more heterogenous across size classes in this sector than they are in the services-sector.

Yet the services sector is far from being homogenous with respect to work schedules. In small as well as large firms operating in distributive services and business services, at least $70 \%$ of men and women work during the daytime. The corresponding percentage is much smaller in consumer

\footnotetext{
${ }^{25}$ Using controls for age, education, tenure, union status, industry and occupation, we estimated a logit model for the probability of being involuntarily employed part-time. We found no significant difference between small and large firms.

${ }^{26}$ The possibility of choosing the time at which one begins and ends their workday is also an important aspect of the timing of work. At the aggregate level, roughly $25 \%$ of employees in small and large firms have flexible schedules. An examination of full-time schedules does not reveal any systematic relationship between firm size and the availability of flexible schedules. Employees working part-time in small firms cite having flexible schedules more often than there counterparts in large firms. This strengthens the idea that part-time jobs are not necessarily bad jobs.

${ }^{27}$ The Survey of Work Arrangements contains information on the actual times of work for the subset of paid workers whose hours do not vary. The majority of workers whose work schedule is a regular, daytime shift report working during daytime. The same is true of night workers: most report working at night. Since the actual work times were not asked to paid workers whose hours vary, it is impossible to test whether all respondents correctly identify their work schedules. However, since most daytime workers report that their actual work times are during the day and most night workers report working evening/overnight hours, we believe that the notion of shift work is reliable. This differs from Hamermesh's (1996) finding that the notion of shift work is too rigid since the majority of people working between 7PM and 10PM do not view themselves as night shift and are not classified as night-shift when their total work schedules are examined.
} 
services - which includes retail trade, hotels and restaurants - where at most 45-65\% of employees work during daytime (Table 13). More importantly, while small firms make greater use of irregular schedules in business services and distributive services, they use such schedules less frequently than large firms in consumer services. Hence, the fact that the use of irregular schedules is as frequent in small firms as it is in large firms when looking at the services sector as a whole masks important size differences within specific service industries.

There are many reasons why a firm may be interested in offering workers alternative work schedules as opposed to regular daytime schedules. First, firms which are capital intensive may find it profitable to have alternate teams of workers operating the same capital stock at different times throughout the day (Oi, 1983; Mayshar and Halevy, 1997). This could explain why shift work is more frequent in large firms. Second, alternative work arrangements may be used to meet temporary increases in demand. The fact that workers in small goods-producing firms are more likely to work on-call, casual or irregular shifts may reflect the possibility that small firms may have a more variable demand for their product and may require/demand a more flexible workforce. Third, because jobs involving on-call and irregular schedules usually provide fewer fringe benefits than other jobs, small plants could use on-call and irregular schedules as a means of reducing labour costs. This could occur in sectors with high degrees of competition or in manufacturing industries which are labour-intensive and for which costs of labour turnover are low. In contrast, the business strategy of large goods-producing firms may emphasize the development of new products and require a highly skilled workforce who could be attracted only by offering jobs with regular schedules (i.e. jobs involving regular daytime schedules or shiftwork). Fourth, the relatively high unionization rates in large firms may restrict large employers' ability to fill vacancies with jobs involving irregular schedules.

As long as workers prefer working during daytime, the greater frequency of shiftwork in large companies is one dimension along which work schedules would be less desirable in large firms. Part of the size-wage differential may reflect large firms' willingness to compensate workers for shiftwork. We now examine this hypothesis.

\section{Does Shiftwork Explain the Employer Size Wage Premium?}

Our examination of work schedules has allowed us to identify a potential explanation for the wage gap between small and large employers. Because shiftwork is more prevalent in large firms of the goods sector, employees in these firms are more likely to work at unusual times and may require higher wages to accept and to remain in their jobs.

To test this hypothesis, we run wage equations in which we add a control for shiftwork to a commonly used set of explanatory variables. We examine how the inclusion of a variable related to shiftwork affects the firm size wage premium. The results are presented in Table 14. Columns 1 and 3 show the firm size coefficients obtained by regressing the (natural logarithm of) hourly wages on a set of controls for age, education, tenure, union status, industry, occupation and firm size. The regressions are run separately for men (column 1) and women (column 3). In columns 2 and 4, we add a dummy variable which equals 1 if an individual works a shift schedule. 
The message is unambiguous: shiftwork cannot explain the wage gap between small and large firms. Whether or not controls for shiftwork are included, men (women) in large firms earn roughly $21 \%(10 \%)$ more than those in small firms in $1995 .^{28} 29$

\section{Summary and Conclusions}

In this paper, we provide recent evidence on job quality by firm size in Canada. Our main findings can be summarized as follows:

1) After controlling for observable worker characteristics and industry-specific effects, the wage gap between small and large employers, measured either at the firm level or at the establishment level, has remained fairly stable between 1986 and 1997. Men and women employed in large firms continued to earn 15-20\% higher wages than those working in small firms;

2) Between 1986 and 1995, the gap in pension coverage between small and large firms has remained unchanged for men. There is some evidence that it has increased for women ;

3) Except for women employed part-time, there is no evidence that the workweek is longer in large firms;

4) In all major industrial groups except manufacturing, employees in small firms work long weeks (i.e. more than five days per week) more often than those in large firms ;

5) The timing of work differs drastically across firm sizes in the goods-producing sector: shiftwork is very rare among small firms but accounts for a substantial fraction of employment in large firms. In contrast, irregular schedules are the exception rather than the rule in large firms but cover $8 \%$ and $15 \%$ of male and female employment, respectively, in small firms. In the services sector as a whole, the timing of work in small companies resembles more that of large companies, especially among women. However, substantial size differences are observed within specific industries of the services sector;

6) A priori, the greater incidence of shiftwork, could explain part of the size-wage differential. However, the inclusion of shiftwork in a wage equation has virtually no impact on the firm size wage premium;

\footnotetext{
${ }^{28}$ Our results are consistent with those of Schmidt and Zimmerman (1991) who use data from West Germany and show that even after controlling for various working conditions, a substantial employer size-wage differential persists.

${ }^{29}$ One may argue that individuals who work on shifts are different from those who work daytime and that part of the size-wage premium reflects individual heterogeneity (e.g. Kostiuk, 1990). If this were the case, adding a shiftwork dummy variable to a wage equation would yield misleading results because of self-selection effects. While this argument has some appeal in the manufacturing sector, it is unlikely to explain the size-wage premium in construction or in business services, where shiftwork accounts for at most $5 \%$ of total employment. In any event, we also ran a wage equation for males employed in the goods sector and found that the inclusion of a dummy variable for shift work had virtually no impact on the coefficient related to the wage gap between large and small firms, which dropped from 0.253 to 0.248 .
} 
Our results also emphasize the need to look at several dimensions of work to assess how job quality varies between small and large firms. On one hand, looking only at the wage gap is clearly insufficient because tremendous differences in pension plan coverage and other fringe benefits exist across size groups and persist over time. On the other hand, there is evidence that some work schedules are superior in small firms. 
Table 1 : Percentage distribution of employment by firm size - Commercial sector

I. Data from LEAP, 1983-1993*

Number of employees in the firm

\begin{tabular}{|c|c|c|c|c|c|}
\hline Year & $\begin{array}{c}(1) \\
1-19\end{array}$ & $\begin{array}{c}(2) \\
20-99\end{array}$ & $\begin{array}{c}(3) \\
100-499\end{array}$ & $\begin{array}{c}(4) \\
500+\end{array}$ & $\begin{array}{c}\text { Total } \\
\text { employment } \\
\text { ('000) }\end{array}$ \\
\hline 1983 & 26.5 & 18.5 & 13.6 & 41.4 & 6,975 \\
\hline 1984 & 26.8 & 19.2 & 14.1 & 39.9 & 7,228 \\
\hline 1985 & 26.7 & 19.4 & 14.4 & 39.5 & 7,556 \\
\hline 1986 & 26.9 & 20.0 & 14.5 & 38.6 & 7,809 \\
\hline 1987 & 26.8 & 20.5 & 14.8 & 37.9 & 8,226 \\
\hline 1988 & 26.5 & 20.7 & 15.1 & 37.7 & 8,512 \\
\hline 1989 & 26.4 & 21.0 & 15.2 & 37.4 & 8,739 \\
\hline 1990 & 26.9 & 21.2 & 14.9 & 37.0 & 8,664 \\
\hline 1991 & 27.0 & 20.7 & 14.9 & 37.4 & 8,456 \\
\hline 1992 & 27.6 & 20.8 & 14.4 & 37.2 & 8,234 \\
\hline 1993 & 27.9 & 20.5 & 14.8 & 36.8 & 8,133 \\
\hline
\end{tabular}

II. Data from household surveys, 1986-1997 : jobs for which firm size is known **

Number of employees in the firm

$\begin{array}{ccccc} & (\mathbf{1}) & \mathbf{( 2 )} & \mathbf{( 3 )} & \mathbf{( 4 )} \\ \text { Year } & \mathbf{1 - 1 9} & \mathbf{2 0 - 9 9} & \mathbf{1 0 0 - 4 9 9} & \mathbf{5 0 0 +} \\ & & & & \\ 1986 & 29.6 & 19.2 & 13.7 & 37.5 \\ 1987 & 28.4 & 19.4 & 13.2 & 39.0 \\ 1988 & 28.8 & 19.6 & 13.1 & 38.4 \\ 1989 & 27.8 & 19.0 & 13.2 & 40.0 \\ 1990 & 28.1 & 19.1 & 12.8 & 40.0 \\ 1993 & 27.1 & 18.4 & 12.9 & 41.5 \\ 1994 & 27.4 & 17.4 & 13.3 & 41.9 \\ 1995 & 27.3 & 18.5 & 12.9 & 41.2 \\ 1997 & 24.8 & 19.0 & 16.3 & 39.8\end{array}$

Data Sources :

* : Longitudinal Employment Analysis Program (LEAP), Statistics Canada.

** : - Labour Market Activity Survey of 1986-1990 and Survey of Labour and Income Dynamics of 1993-1995: jobs held in September by paid workers aged 17-64 who are employed in the commercial sector.

- Labour Force Survey of 1997 : main job held in September by paid workers aged 17-64 who are employed in the commercial sector. 
Table 2: Average hourly wages by firm size, full-time jobs, 1986-1997

\section{Men employed in full-time jobs}

\begin{tabular}{|c|c|c|c|c|c|}
\hline \multirow[b]{3}{*}{ Year } & (1) & (2) & (3) & (4) & \multirow{3}{*}{$\begin{array}{c}(5) \\
\text { Raw wage gap } \\
{[(4) /(1)] \text { - } 1}\end{array}$} \\
\hline & Firm size & \multicolumn{3}{|c|}{ (number of employees) } & \\
\hline & 1-19 & $20-99$ & $100-499$ & $500+$ & \\
\hline 1986 & 10.27 & 12.04 & 12.30 & 14.94 & $45.5 \%$ \\
\hline 1987 & 10.71 & 12.31 & 13.83 & 15.57 & $45.4 \%$ \\
\hline 1988 & 11.62 & 13.45 & 14.80 & 16.63 & $43.1 \%$ \\
\hline 1989 & 11.86 & 14.21 & 15.39 & 17.26 & $45.5 \%$ \\
\hline 1990 & 12.53 & 14.59 & 16.34 & 17.78 & $41.9 \%$ \\
\hline 1993 & 13.44 & 16.29 & 16.67 & 19.69 & $46.5 \%$ \\
\hline 1994 & 14.42 & 15.94 & 17.96 & 20.16 & $39.8 \%$ \\
\hline 1995 & 14.14 & 15.94 & 18.83 & 20.74 & $46.7 \%$ \\
\hline 1997 & 13.87 & 15.30 & 16.73 & 20.16 & $45.3 \%$ \\
\hline
\end{tabular}

(1)

Firm size

\section{Year}

1986

1987

1988

1989

1990

1993

1994

1995

1997
1-19

6.72

7.61

8.32

8.87

8.89

10.40

11.06

10.96

10.95
(2)

(3)

(4)

(number of employees)

20-99 100-499 500+

$\begin{array}{lll}8.04 & 9.23 \quad 10.38\end{array}$

$\begin{array}{lll}8.67 & 9.66 & 10.80\end{array}$

$\begin{array}{lll}9.58 & 10.41 \quad 11.62\end{array}$

$\begin{array}{lll}9.61 & 11.43 & 12.00\end{array}$

$\begin{array}{lll}10.31 & 11.62 \quad 12.58\end{array}$

11.24

11.81

12.21

11.72
$11.62 \quad 12.58$

$12.18 \quad 14.67$

$13.17 \quad 14.88$

$13.12 \quad 14.76$

$12.73 \quad 14.93$
(5)

Raw wage gap

$[(4) /(1)]-1$

$54.5 \%$

$41.9 \%$

$39.7 \%$

$35.3 \%$

$41.5 \%$

$41.1 \%$

$34.5 \%$

$34.7 \%$

$36.3 \%$

* For LMAS 1986-1990 and SLID 1993-1995, the sample consists of full-time jobs held in September by paid workers aged 17-64, who were not full-time students at any time during the year and who were employed in the commercial sector. For LFS 1997, the sample consists of main full-time jobs held in September by paid workers aged 17-64, who are not full-time students in September and who are employed in the commercial sector.

Source : Labour Market Activity Survey of 1986-1990

Survey of Labour and Income Dynamics of 1993-1995

Labour Force Survey of September 1997 
Table 3: Wage differential between small and larger firms, full-time jobs, 1986-1997

\begin{tabular}{|c|c|c|c|c|c|c|c|c|c|}
\hline & 1986 & 1987 & 1988 & 1989 & 1990 & 1993 & 1994 & 1995 & 1997 \\
\hline \multicolumn{10}{|l|}{ I. Men } \\
\hline \multicolumn{10}{|c|}{ No controls for occupation } \\
\hline $\mathrm{F} 2$ & 0.103 & 0.104 & 0.097 & 0.129 & 0.129 & 0.144 & 0.076 & 0.109 & 0.088 \\
\hline F3 & 0.183 & 0.166 & 0.166 & 0.176 & 0.198 & 0.177 & 0.166 & 0.205 & 0.113 \\
\hline F4 & 0.246 & 0.253 & 0.242 & 0.258 & 0.251 & 0.268 & 0.226 & 0.258 & 0.259 \\
\hline Adj. R squared & 0.3293 & 0.3327 & 0.3066 & 0.3192 & 0.3151 & 0.4089 & 0.3855 & 0.4302 & 0.3843 \\
\hline \multicolumn{10}{|c|}{ Controls for occupation included } \\
\hline $\mathrm{F} 2$ & 0.093 & 0.099 & 0.086 & 0.123 & 0.119 & 0.108 & 0.064 & 0.088 & 0.073 \\
\hline F3 & 0.161 & 0.144 & 0.147 & 0.159 & 0.178 & 0.141 & 0.122 & 0.178 & 0.079 \\
\hline F4 & 0.209 & 0.222 & 0.21 & 0.235 & 0.219 & 0.212 & 0.181 & 0.215 & 0.2 \\
\hline Adj. R squared & 0.3894 & 0.3913 & 0.3639 & 0.3673 & 0.3797 & 0.4921 & 0.472 & 0.5104 & 0.5048 \\
\hline Sample size & 11,925 & 14,381 & 11,628 & 10,671 & 10,398 & 4,430 & 4,790 & 4,762 & 3,092 \\
\hline \multicolumn{10}{|l|}{ II. Women } \\
\hline \multicolumn{10}{|c|}{ No controls for occupation } \\
\hline $\mathrm{F} 2$ & 0.139 & 0.092 & 0.097 & 0.066 & 0.089 & $0.035^{*}$ & 0.07 & 0.088 & 0.07 \\
\hline F3 & 0.213 & 0.146 & 0.158 & 0.153 & 0.151 & 0.12 & 0.1 & 0.13 & 0.111 \\
\hline $\mathrm{F} 4$ & 0.275 & 0.21 & 0.221 & 0.198 & 0.203 & 0.197 & 0.216 & 0.163 & 0.201 \\
\hline Adj. R squared & 0.362 & 0.3293 & 0.2805 & 0.2929 & 0.3091 & 0.4324 & 0.4622 & 0.4371 & 0.4589 \\
\hline \multicolumn{10}{|c|}{ Controls for occupation included } \\
\hline $\mathrm{F} 2$ & 0.122 & 0.076 & 0.086 & 0.058 & 0.082 & $0.025^{*}$ & 0.063 & 0.078 & $0.050 *$ \\
\hline F3 & 0.188 & 0.119 & 0.143 & 0.133 & 0.132 & 0.101 & 0.084 & 0.108 & 0.096 \\
\hline $\mathrm{F} 4$ & 0.247 & 0.189 & 0.194 & 0.169 & 0.183 & 0.154 & 0.198 & 0.136 & 0.163 \\
\hline Adj. R squared & 0.4238 & 0.3918 & 0.3429 & 0.3513 & 0.3611 & 0.5081 & 0.5301 & 0.5132 & 0.5473 \\
\hline Sample size & 5,955 & 7,432 & 5,946 & 5,545 & 5,449 & 2,342 & 2,514 & 2,531 & 1,608 \\
\hline
\end{tabular}

*: not statistically significant at the $1 \%$ level (two-tailed test)

Note : F2 (F4) refers to firms with 20-99 (500+) employees. Firms with 1-19 employees are the reference group. The percentage wage differential between small and larger firms equals the antilog of the regression coefficients shown in this table minus 1 . See Table 4 for data sources and sample definition.

- The dependent variable is the natural logarithm of hourly wages. The set of controls includes a constant, age, age squared, marital status, union status, industry (2-digit level), province and firm size. Controls for occupation (2-digit level) are omitted in the first specification and included in the second. 
(1)

Firm size

Year

1986

1987

1988

1989

1990

1993

1994

1995

$\begin{array}{lrrrr}\mathbf{1 - 1 9} & \mathbf{2 0 - 9 9} & \mathbf{1 0 0 - 4 9 9} & \mathbf{5 0 0 +} & \text { All firms } \\ 15.9 & 32.6 & 54.0 & 77.4 & \\ 14.7 & 30.1 & 51.9 & 75.9 & 49.7 \\ 17.2 & 30.9 & 52.0 & 77.1 & 48.2 \\ 17.4 & 32.6 & 57.1 & 76.0 & 49.6 \\ 17.3 & 36.8 & 55.1 & 75.0 & 51.0 \\ & & & & 50.7 \\ 13.5 & 31.0 & 51.0 & 74.1 & 49.5 \\ 15.6 & 29.0 & 59.0 & 76.9 & 51.2 \\ 13.3 & 33.2 & 53.5 & 73.6 & 48.4\end{array}$

\section{Women}

(1)

(2)

(3) (4)

(5)

Firm size (number of employees)

$\begin{array}{lccccc}\text { Year } & \mathbf{1 - 1 9} & \mathbf{2 0 - 9 9} & \mathbf{1 0 0 - 4 9 9} & \mathbf{5 0 0 +} & \text { All firms } \\ 1986 & 7.0 & 19.3 & 34.9 & 53.8 & 29.6 \\ 1987 & 6.9 & 19.8 & 32.3 & 53.3 & 29.7 \\ 1988 & 7.8 & 20.2 & 39.9 & 56.9 & 31.9 \\ 1989 & 7.2 & 20.1 & 40.0 & 57.6 & 32.9 \\ 1990 & 7.6 & 23.6 & 38.2 & 57.6 & 33.3 \\ 1993 & & & & & 33.3 \\ 1994 & 5.4 & 19.5 & 42.7 & 60.9 & 30.9 \\ 1995 & 4.8 & 23.5 & 34.0 & 57.7 & 53.2 \\ \end{array}$

* Percentage of workers who respond yes to the following question : "Are you covered by a pension plan connected with this job ? (Do not count CPP/QPP, deferred profit sharing plans or personal savings plans for retirement)."

The sample consists of jobs (full-time and part-time) held in September by paid workers aged 17-64, who were not full-time students at any time during the year and who were employed in the commercial sector.

Source : Labour Market Activity Survey of 1986-1990

Survey of Labour and Income Dynamics of 1993-1995 
Table 5: Percentage of workers covered by specific fringe benefits by firm size

\begin{tabular}{|c|c|c|c|c|c|}
\hline & \multicolumn{4}{|c|}{ Firm size (number of employees) } & \multirow[b]{2}{*}{$\begin{array}{c}\text { All firms } \\
(\mathbf{5})\end{array}$} \\
\hline & $\begin{array}{c}1-19 \\
(1)\end{array}$ & $\begin{array}{c}20-99 \\
(2)\end{array}$ & $\begin{array}{c}100-499 \\
(3)\end{array}$ & $\begin{array}{c}500+ \\
(4)\end{array}$ & \\
\hline \multicolumn{6}{|l|}{ I. All workers $(N=13,542)$} \\
\hline Medical/Health insurance & 23.1 & 56.4 & 69.5 & 79.5 & 59.5 \\
\hline Dental plan & 19.7 & 50.9 & 63.8 & 78 & 56.1 \\
\hline Vacation leave & 58.8 & 77.5 & 79.8 & 86 & 76.7 \\
\hline Sick leave & 27.7 & 46.9 & 61.7 & 71.2 & 54.3 \\
\hline \multicolumn{6}{|l|}{ II. Men $(\mathbf{N}=\mathbf{8 , 1 3 7})$} \\
\hline Medical/Health insurance & 27 & 60.3 & 73.8 & 85.4 & 65 \\
\hline Dental plan & 23.2 & 55.2 & 67.4 & 84.1 & 61.5 \\
\hline Vacation leave & 59.7 & 78.3 & 81.9 & 89.7 & 79.2 \\
\hline Sick leave & 26.6 & 47.3 & 63.2 & 74.1 & 55.9 \\
\hline \multicolumn{6}{|l|}{ II. Women $(\mathrm{N}=\mathbf{5 , 4 0 5})$} \\
\hline Medical/Health insurance & 18.5 & 49.4 & 62.7 & 70.9 & 51.7 \\
\hline Dental plan & 15.5 & 43.4 & 58.1 & 69.2 & 48.4 \\
\hline Vacation leave & 57.8 & 76.2 & 76.6 & 80.8 & 73.1 \\
\hline Sick leave & 29 & 46.4 & 59.5 & 67 & 52 \\
\hline
\end{tabular}

Source : Survey of Work Arrangements of 1995 
I. Average usual weekly hours

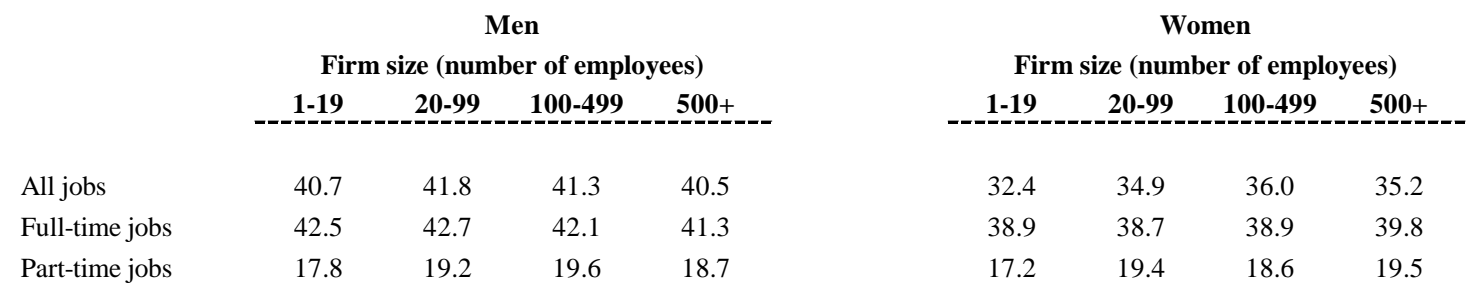

II. OLS regression results of usual weekly hours*



Note: * The dependent variable is the number of usual weekly hours. Controls for age, education, tenure, union status, industry and occupation are also included. F2 (F4) refers to firms with 20-99 (500+) employees : firms with 1-19 employees are the reference group. Absolute values of t-statistics are between parentheses.

Source : Survey of Work Arrangements of 1995 
Table 7: Usual paid hours worked on a regular basis, by firm size

\section{Average usual paid hours worked on a regular basis}

\begin{tabular}{|c|c|c|c|c|}
\hline & Fir & ze (num & r of empl & es) \\
\hline & 1-19 & $20-99$ & $100-499$ & $500+$ \\
\hline All jobs & 39.4 & 40.3 & 39.6 & 38.6 \\
\hline Full-time jobs & 41.2 & 41.2 & 40.4 & 39.2 \\
\hline Part-time jobs & 17.3 & 19.0 & 19.6 & 18.6 \\
\hline
\end{tabular}

\begin{tabular}{|cccc}
\multicolumn{5}{c}{ Women } \\
\multicolumn{4}{c}{ Firm size (number of employees) } \\
$\mathbf{1 - 1 9}$ & $\mathbf{2 0 - 9 9}$ & $\mathbf{1 0 0 - 4 9 9}$ & $\mathbf{5 0 0 +}$ \\
\hline & & & \\
31.9 & 34.6 & 35.4 & 34.2 \\
38.3 & 38.4 & 38.2 & 37.7 \\
16.9 & 19.3 & 18.2 & 19.1
\end{tabular}

II. OLS regression results of usual paid hours worked on a regular basis*

\begin{tabular}{|c|c|c|c|c|c|c|c|c|c|c|}
\hline \multirow[b]{3}{*}{ Industry groups } & \multicolumn{10}{|c|}{ Men } \\
\hline & \multicolumn{5}{|c|}{ All jobs } & \multicolumn{5}{|c|}{ Full-time jobs } \\
\hline & 8 & 16 & 52 & 16 & 52 & 8 & 16 & 52 & 16 & 52 \\
\hline Occupation groups & 8 & 24 & 24 & 50 & 50 & 8 & 24 & 24 & 50 & 50 \\
\hline $\mathrm{F} 2$ & $\begin{array}{c}0.51 \\
(1.68)\end{array}$ & $\begin{array}{c}0.51 \\
(1.67)\end{array}$ & $\begin{array}{c}0.48 \\
(1.61)\end{array}$ & $\begin{array}{c}0.65 \\
(2.16)\end{array}$ & $\begin{array}{c}0.59 \\
(1.96)\end{array}$ & $\begin{array}{c}0.05 \\
(0.18)\end{array}$ & $\begin{array}{l}-0.01 \\
(0.05)\end{array}$ & $\begin{array}{l}-0.01 \\
(0.02)\end{array}$ & $\begin{array}{c}0.08 \\
(0.31)\end{array}$ & $\begin{array}{c}0.06 \\
(0.22)\end{array}$ \\
\hline F3 & $\begin{array}{c}-0.30 \\
(0.90)\end{array}$ & $\begin{array}{l}-0.19 \\
(0.58)\end{array}$ & $\begin{array}{l}-0.10 \\
(0.32)\end{array}$ & $\begin{array}{c}-0.02 \\
(0.07)\end{array}$ & $\begin{array}{c}0.02 \\
(0.07)\end{array}$ & $\begin{array}{c}-0.61 \\
(2.16)\end{array}$ & $\begin{array}{l}-0.53 \\
(1.92)\end{array}$ & $\begin{array}{l}-0.44 \\
(1.56)\end{array}$ & $\begin{array}{l}-0.40 \\
(1.43)\end{array}$ & $\begin{array}{l}-0.34 \\
(1.23)\end{array}$ \\
\hline $\mathrm{F} 4$ & $\begin{array}{l}-1.21 \\
(4.10)\end{array}$ & $\begin{array}{l}-1.07 \\
(3.62)\end{array}$ & $\begin{array}{l}-0.87 \\
(2.91)\end{array}$ & $\begin{array}{c}-0.98 \\
(3.29)\end{array}$ & $\begin{array}{c}-0.84 \\
(2.80)\end{array}$ & $\begin{array}{l}-1.46 \\
(5.79)\end{array}$ & $\begin{array}{l}-1.43 \\
(5.65)\end{array}$ & $\begin{array}{l}-1.22 \\
(4.76)\end{array}$ & $\begin{array}{l}-1.31 \\
(5.14)\end{array}$ & $\begin{array}{l}-1.16 \\
(4.50)\end{array}$ \\
\hline \multirow[t]{3}{*}{ Sample size } & 8,137 & 8,137 & 8,137 & 8,137 & 8,137 & 7,753 & 7,753 & 7,753 & 7,753 & 7,753 \\
\hline & \multicolumn{10}{|c|}{ Women } \\
\hline & \multicolumn{5}{|c|}{ All jobs } & \multicolumn{5}{|c|}{ Full-time jobs } \\
\hline Industry groups & 8 & 16 & 52 & 16 & 52 & 8 & 16 & 52 & 16 & 52 \\
\hline Occupation groups & 8 & 24 & 24 & 50 & 50 & 8 & 24 & 24 & 50 & 50 \\
\hline $\mathrm{F} 2$ & $\begin{array}{c}1.30 \\
(3.25)\end{array}$ & $\begin{array}{c}1.44 \\
(3.56)\end{array}$ & $\begin{array}{c}1.51 \\
(3.69)\end{array}$ & $\begin{array}{c}1.46 \\
(3.60)\end{array}$ & $\begin{array}{c}1.36 \\
(3.33)\end{array}$ & $\begin{array}{l}-0.10 \\
(0.39)\end{array}$ & $\begin{array}{l}-0.10 \\
(0.38)\end{array}$ & $\begin{array}{c}0.01 \\
(0.04)\end{array}$ & $\begin{array}{c}0.02 \\
(0.07)\end{array}$ & $\begin{array}{l}-0.06 \\
(0.21)\end{array}$ \\
\hline $\mathrm{F} 3$ & $\begin{array}{c}1.67 \\
(3.98)\end{array}$ & $\begin{array}{c}1.95 \\
(4.61)\end{array}$ & $\begin{array}{c}2.00 \\
(4.73)\end{array}$ & $\begin{array}{c}2.18 \\
(5.18)\end{array}$ & $\begin{array}{c}2.07 \\
(4.89)\end{array}$ & $\begin{array}{l}-0.31 \\
(1.18)\end{array}$ & $\begin{array}{l}-0.26 \\
(0.96)\end{array}$ & $\begin{array}{l}-0.12 \\
(0.44)\end{array}$ & $\begin{array}{l}-0.10 \\
(0.37)\end{array}$ & $\begin{array}{l}-0.15 \\
(0.56)\end{array}$ \\
\hline F4 & $\begin{array}{c}0.59 \\
(1.72)\end{array}$ & $\begin{array}{c}0.73 \\
(2.06)\end{array}$ & $\begin{array}{c}1.03 \\
(2.80)\end{array}$ & $\begin{array}{c}0.94 \\
(2.63)\end{array}$ & $\begin{array}{c}0.98 \\
(2.69)\end{array}$ & $\begin{array}{l}-0.77 \\
(3.42)\end{array}$ & $\begin{array}{l}-0.66 \\
(2.83)\end{array}$ & $\begin{array}{l}-0.48 \\
(2.00)\end{array}$ & $\begin{array}{c}0.51 \\
(2.20)\end{array}$ & $\begin{array}{l}-0.52 \\
(2.19)\end{array}$ \\
\hline Sample size & 5,405 & 5,405 & 5,405 & 5,405 & 5,405 & 4,119 & 4,119 & 4,119 & 4,119 & 4,119 \\
\hline
\end{tabular}

\footnotetext{
* The dependent variable is the number of usual paid hours worked on a regular basis. Controls for age, education, tenure, union status, industry and occupationare also included. F2 (F4) refers to firms with 20-99 (500+) employees : firms with 1-19 employees are the reference group. Absolute values of t-statistics are between parentheses.
}

Source : Survey of Work Arrangements of 1995 
Table 8: Length of the workweek in small and large firms *

\begin{tabular}{|c|c|c|c|}
\hline & All jobs & Full-time jobs & Part-time jobs \\
\hline \multicolumn{4}{|l|}{ I. Men } \\
\hline \multicolumn{4}{|l|}{ Concept of hours used : } \\
\hline a) Total usual weekly hours & no difference & no difference & no difference \\
\hline $\begin{array}{l}\text { b) Usual paid hours worked } \\
\text { on a regular basis }\end{array}$ & $\begin{array}{l}\text { workweek is longer } \\
\text { in small firms }\end{array}$ & $\begin{array}{l}\text { workweek is longer } \\
\text { in small firms }\end{array}$ & no difference \\
\hline \multicolumn{4}{|l|}{ I. Women } \\
\hline \multicolumn{4}{|l|}{ Concept of hours used : } \\
\hline a) Total usual weekly hours & $\begin{array}{l}\text { workweek is shorter } \\
\text { in small firms }\end{array}$ & no difference & $\begin{array}{l}\text { workweek is shorter } \\
\text { in small firms }\end{array}$ \\
\hline $\begin{array}{l}\text { b) Usual paid hours worked } \\
\text { on a regular basis }\end{array}$ & $\begin{array}{l}\text { workweek is shorter } \\
\text { in small firms }\end{array}$ & $\begin{array}{l}\text { workweek is longer } \\
\text { in small firms }\end{array}$ & $\begin{array}{l}\text { workweek is shorter } \\
\text { in small firms }\end{array}$ \\
\hline
\end{tabular}

Note: * This table summarizes the second panel of Tables 8 and 9. Results on part-time jobs are not shown in these tables but are available from the authors upon request. The term "no difference" refers to the absence of a statistically significant difference at the $5 \%$ level.

Source : Survey of Work Arrangements of 1995 
All employees $(\mathbf{N}=\mathbf{1 3}, \mathbf{5 4 2})$

\begin{tabular}{|c|c|c|c|c|c|c|c|c|c|c|}
\hline \multirow{3}{*}{ Hours per day } & \multicolumn{5}{|c|}{ Firms with less than 20 employees } & \multicolumn{5}{|c|}{ Firms with 500 or more employees } \\
\hline & \multicolumn{5}{|c|}{ Days per week } & \multicolumn{5}{|c|}{ Days per week } \\
\hline & $1-4$ & 5 & $6-7$ & Days vary & Total & $1-4$ & 5 & $6-7$ & Days vary & Total \\
\hline Less than 7 hours & 1.7 & 4 & 1.2 & 0.9 & 7.7 & 1.1 & 1.6 & 0.2 & 1 & 3.9 \\
\hline 7 - 8 hours & 4 & 40.5 & 2.7 & 3.5 & 50.7 & 1.1 & 52 & 1.8 & 5.8 & 60.7 \\
\hline More than 8 hours & 1.3 & 8.5 & 2.4 & 1.1 & 13.3 & 1.3 & 7.5 & 1.5 & 4.1 & 14.4 \\
\hline Hours vary & 2.8 & 10.6 & 5.9 & 9 & 28.4 & 1.4 & 9 & 2.1 & 8.5 & 21 \\
\hline Total & 9.7 & 63.6 & 12.2 & 14.5 & 100 & 4.8 & 70.8 & 5.7 & 19.5 & 100 \\
\hline
\end{tabular}

$\operatorname{Men}(\mathbf{N}=\mathbf{8 , 1 3 7})$

\begin{tabular}{|c|c|c|c|c|c|c|c|c|c|c|}
\hline \multirow{3}{*}{ Hours per day } & \multicolumn{10}{|c|}{$\operatorname{Men}(N=8,137)$} \\
\hline & \multicolumn{5}{|c|}{ Days per week } & \multicolumn{5}{|c|}{ Days per week } \\
\hline & $1-4$ & 5 & $6-7$ & Days vary & Total & $1-4$ & 5 & $6-7$ & Days vary & Total \\
\hline Less than 7 hours & 0.4 & 1.9 & 1.1 & 0.3 & 3.7 & 0.2 & 0.8 & 0.2 & 0.4 & 1.6 \\
\hline 7 - 8 hours & 1.3 & 43 & 2.7 & 3.1 & 50.1 & 0.6 & 51.7 & 2.4 & 6.3 & 61 \\
\hline More than 8 hours & 1 & 12.9 & 3.7 & 1.5 & 19.1 & 2.3 & 9.1 & 2.4 & 6.3 & 20.1 \\
\hline Hours vary & 1.5 & 12 & 6.8 & 7.1 & 27.4 & 0.8 & 9 & 2 & 6 & 17.7 \\
\hline Total & 4.2 & 69.8 & 14.3 & 12 & 100 & 3.7 & 70.4 & 7 & 18.9 & 100 \\
\hline
\end{tabular}

Women $(\mathbf{N}=\mathbf{5}, \mathbf{4 0 5})$

\begin{tabular}{|c|c|c|c|c|c|c|c|c|c|c|}
\hline \multirow{3}{*}{ Hours per day } & \multicolumn{10}{|c|}{ Women $(N=5,405)$} \\
\hline & \multicolumn{5}{|c|}{ Days per week } & \multicolumn{5}{|c|}{ Days per week } \\
\hline & $1-4$ & 5 & $6-7$ & Days vary & Total & $1-4$ & 5 & $6-7$ & Days vary & Total \\
\hline Less than 7 hours & 3.4 & 6.6 & 1.1 & 1.7 & 12.8 & 2.2 & 3 & 0.3 & 1.9 & 7.4 \\
\hline 7 - 8 hours & 7.3 & 37.5 & 2.8 & 4.1 & 51.7 & 1.8 & 52.5 & 1.2 & 5.3 & 60.8 \\
\hline More than 8 hours & 1.4 & 3.1 & 0.8 & 0.6 & 5.9 & 0.2 & 5.1 & 0.1 & 1 & 6.4 \\
\hline Hours vary & 4.4 & 9 & 4.9 & 11.4 & 29.7 & 2.2 & 9.1 & 2.4 & 12.1 & 25.7 \\
\hline Total & 16.4 & 56.2 & 9.5 & 17.8 & 100 & 6.4 & 69.6 & 3.8 & 20.3 & 100 \\
\hline
\end{tabular}

Source: Survey of Work Arrangements, 1995 
Table 10 : Percentage of employees working more than five days per week, by industry and firm size

\begin{tabular}{lccccc}
\hline & \multicolumn{7}{c}{ Firm size (number of employees) } \\
Industry & $\mathbf{1 - 1 9}$ & $\mathbf{2 0 - 9 9}$ & $\mathbf{1 0 0 - 4 9 9}$ & $\mathbf{5 0 0 +}$ & All firms \\
& & & & & \\
Forestry and mining & 16.6 & 28.7 & 8.5 & 9.1 & 12.8 \\
Construction & 12.6 & 4.4 & 6.7 & 4.7 & 9.1 \\
Manufacturing & 6.8 & 5 & 4.1 & 5.7 & 5.2 \\
Distributive services & 9.9 & 10.4 & 6.6 & 3.3 & 6.4 \\
Business services & 7.4 & 4.8 & 7.2 & 3.6 & 11.3 \\
Consumer services & 16 & 7.7 & 9.1 & 8.9 & 7.7 \\
& & & & & 5.7 \\
All industries & 12.1 & 7.2 & 6.5 & & \\
\end{tabular}

Source : Survey of Work Arrangements of 1995 
Table 11: Work schedules in large and small firms - Results from logit models

Men

Women

I. Probability of working 35 - 40 hours and 5 days per week

... in firms with less than 20 workers

$51.9 \%$

$41.7 \%$

$\ldots$ in firms with 20 - 99 workers

$57.4 \%$

$53.7 \%$

... in firms with 100 - 499 workers

$57.0 \%$

$55.7 \%$

$\ldots$ in firms with 500 or more workers

$50.9 \%$

$49.3 \%$

II. Probability of working more than 5 days per week

... in firms with less than 20 workers

$10.3 \%$

$6.9 \%$

$7.1 \%$

... in firms with 20 - 99 workers

$5.9 \%$

$3.4 \%$

$\ldots$ in firms with $100-499$ workers

$6.2 \%$

$5.1 \%$

$\ldots$ in firms with 500 or more workers

$3.5 \%$

III. Probability of working less than 5 days per week

... in firms with less than 20 workers

$3.3 \%$

$2.4 \%$

$15.5 \%$

$\ldots$ in firms with 20 - 99 workers

$2.7 \%$

$12.1 \%$

... in firms with 100 - 499 workers

$3.2 \%$

$8.1 \%$

$\ldots$ in firms with 500 or more workers

$7.5 \%$

Note: Regressors include an intercept, age, education, tenure, union status, occupation, industry (52 groups) and firm size. The probabilities presented in this table are based on the mean values of the explanatory variables that are statisitcally siginifcant at the 5\% level. Coefficients of regressors which are not statsitically significant are set to zero.

Source: Survey of Work Arrangements, 1995 
Table 12: Percentage of employees by work schedule type, by sector and firm size

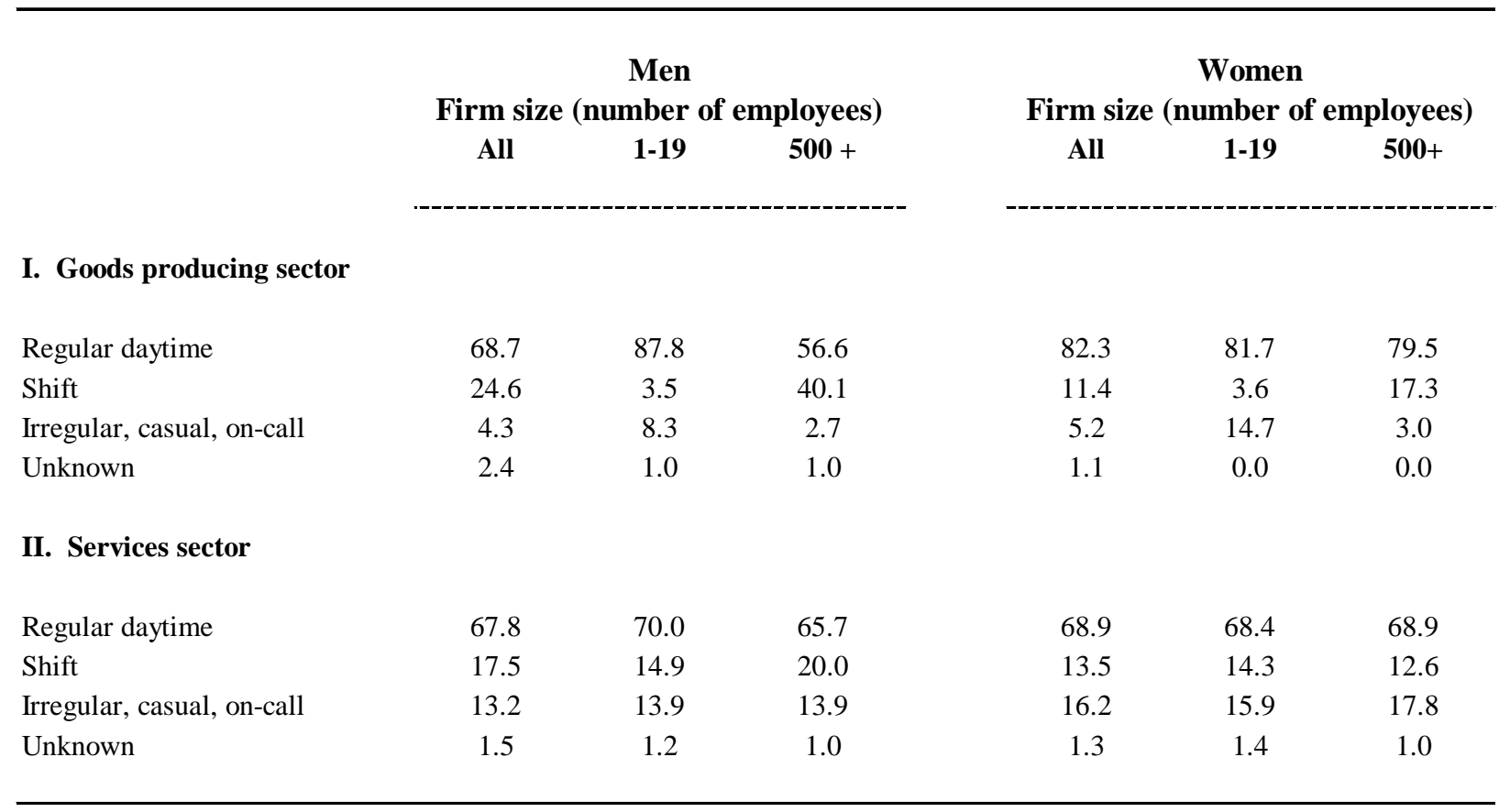

Source: Survey of Work Arrangements, 1995

Note: Shift refers to persons working night, evening, rotating or split shifts. 
Table 13: Percentage of employees by schedule type, by industry and firm size

\begin{tabular}{|c|c|c|c|c|c|c|}
\hline & \multicolumn{3}{|c|}{$\begin{array}{c}\text { Men } \\
\text { Firm size (number of employees) }\end{array}$} & \multicolumn{3}{|c|}{$\begin{array}{c}\text { Women } \\
\text { Firm size (number of employees) }\end{array}$} \\
\hline & All firms & $1-19$ & $500+$ & All firms & $1-19$ & $500+$ \\
\hline \multicolumn{7}{|l|}{ I. Forestry and Mining } \\
\hline Regular daytime & 59.3 & 86.0 & 54.0 & - & - & - \\
\hline Shift & 31.0 & 5.0 & 41.3 & - & - & - \\
\hline Irregular, casual, on-call & 5.4 & 7.2 & 3.2 & - & - & - \\
\hline Unknown & 4.4 & 1.9 & 1.5 & - & - & - \\
\hline \multicolumn{7}{|l|}{ II. Construction } \\
\hline Regular daytime & 87.5 & 89.8 & 90.0 & - & - & - \\
\hline Shift & 3.3 & 1.0 & 7.8 & - & - & - \\
\hline Irregular, casual, on-call & 6.0 & 9.2 & 2.2 & - & - & - \\
\hline Unknown & 3.3 & 0.0 & 0.0 & - & - & - \\
\hline \multicolumn{7}{|l|}{ III. Manufacturing } \\
\hline Regular daytime & 64.5 & 85.7 & 55.1 & 82.5 & 86.1 & 78.7 \\
\hline Shift & 30.0 & 6.0 & 41.7 & 12.2 & 3.9 & 18.5 \\
\hline Irregular, casual, on-call & 3.7 & 7.4 & 2.6 & 4.1 & 10.0 & 2.6 \\
\hline Unknown & 1.9 & 0.9 & 0.6 & 1.2 & 0.0 & 0.2 \\
\hline \multicolumn{7}{|l|}{ IV. Distributive services } \\
\hline Regular daytime & 71.5 & 77.3 & 69.9 & 83.1 & 80.3 & 83.6 \\
\hline Shift & 14.8 & 8.2 & 17.1 & 7.8 & 2.3 & 8.3 \\
\hline Irregular, casual, on-call & 12.3 & 13.6 & 12.2 & 7.8 & 16.0 & 7.4 \\
\hline Unknown & 1.5 & 1.0 & 0.8 & 1.3 & 1.5 & 0.7 \\
\hline \multicolumn{7}{|l|}{ V. Business services } \\
\hline Regular daytime & 79.5 & 73.1 & 81.6 & 89.5 & 87.8 & 89.9 \\
\hline Shift & 8.2 & 8.1 & 8.9 & 3.3 & 2.9 & 4.4 \\
\hline Irregular, casual, on-call & 11.0 & 18.0 & 9.5 & 6.4 & 8.5 & 5.5 \\
\hline Unknown & 1.3 & 0.8 & 0.0 & 0.8 & 0.8 & 0.2 \\
\hline \multicolumn{7}{|l|}{ VI. Consumer services } \\
\hline Regular daytime & 57.4 & 65.0 & 46.0 & 51.9 & 58.6 & 45.1 \\
\hline Shift & 25.6 & 20.8 & 33.6 & 21.6 & 20.9 & 21.3 \\
\hline Irregular, casual, on-call & 15.5 & 12.9 & 20.1 & 24.9 & 18.9 & 32.6 \\
\hline Unknown & 1.6 & 1.3 & 0.3 & 1.6 & 1.6 & 1.0 \\
\hline
\end{tabular}

Note: Shift refers to persons working night, evening, rotating or split shifts.

Source: Survey of Work Arrangements, 1995 
Table 14 : Shiftwork and the firm size wage differential

Source:

Selected coefficients

(1)

Male workers

(2)
Female workers

(3)

Firm size coefficients

F2

F3

F4

Shiftwork

Adj. R squared

Sample size
0.047

0.138

(9.68)

0.194

(14.98)

$-$

0.532

5,843
0.047

(3.50)

0.139

(9.72)

0.195

(14.92)

$-0.01$

$(-0.94)$

0.532

5,843
0.011

(0.77)

0.043

(2.78)

0.098

(7.73)

$-0.02$

0.532

0.533

4,232

4,232

Note : Absolute values of t-statistics are in parentheses. F2 (F4) refers to firms with 20-99 (500+) employees.

Firms with 1-19 employees are the reference group. The percentage wage differential between small and larger firms equals the antilog of the size coefficients shown in this table minus 1. The sample consists of paid workers aged 15-64 who are not full-time students and who are employed in the commercial sector. See text for more details. 


\section{Appendix 1: Data Sources}

\section{Data sets used:}

The Labour Market Activity Survey (LMAS) is the first Canadian household survey to ask individuals information about firm size. The LMAS is based upon a sub-sample of the Labour Force Survey (LFS) design: it is administered to 5 of the 6 LFS rotation groups. The surveyed population consists of all civilian, non-institutionalized persons aged 16 to 69, who are residents of the ten Canadian provinces. The survey yields two panels, one for the 1986-87 period and one for the 198890 period. In 1987, 1989 and 1990, a small sample of individuals was added to allow the construction of cross-sectional data sets for all years of the 1986-1990 period.

The Survey of Labour and Income Dynamics (SLID) is - to date - a three-year longitudinal household survey which contains information on firm size. SLID is based upon 2 of the 6 LFS rotation groups resulting in a smaller sample size than LMAS. Similar to LMAS, SLID yields both cross-sectional and longitudinal data sets. We use the cross-sectional data sets for 1993, 1994 and 1995.

The Survey of Work Arrangements (SWA) of November 1995 samples 3 of the 6 LFS rotation groups and provides information on work schedules. In September 1997, the Labour Force Survey (LFS) included questions on firm size. The September file of LFS 1997 consists of 1 of the 6 LFS rotation groups and yields a sample of roughly 10,000 workers. ${ }^{30}$

\section{Calculation of hourly wage rates:}

While LMAS, SLID, SWA and LFS are all based on the LFS sample design, they differ slightly in the way they calculate hourly wage rates.

In LMAS paid workers are asked:

1) how many weeks they usually work per month,

2) how many paid days they usually work per week and,

3) how many paid hours they usually work per day.

The number of weekly hours is not allowed to vary during the course of the year. Hourly wage rates are obtained by dividing the reported earnings (e.g. annual, monthly, weekly earnings) by the number of paid hours worked during the relevant time interval ${ }^{31}$.

\footnotetext{
${ }^{30}$ LMAS, SLID, SWA and LFS ask individuals: 1) how many persons are employed at the location where they work, 2) how many persons are employed at all the locations owned by the employer in Canada. Popular data sets such as the Survey of Consumer Finances and the Census do not have data on firm size. The Survey of Employment, Payroll and Hours (SEPH) is an establishment survey which contains information on establishment size and firm size. However, it does not contain information on worker characteristics. The Census of Manufactures measures establishment size and firm size but - apart from the distinction between production and non-production workers - has no details on worker characteristics.

${ }^{31}$ The calculations take into account the fact that a month includes on average 4.35 weeks (i.e. 4 weeks* (365 days /(4 weeks *12 months*7 days).
} 
In SLID, paid workers are asked:

1) if they usually work every week of the month and if not, how many weeks they usually work per month and,

2) how many paid hours they usually work per week.

Contrary to LMAS, SLID allows workers to report changes in the number of weekly hours usually worked. For paid workers who are not on-call or who do not have an irregular schedule, SLID asks additional questions to check if the number of usual weekly hours worked for the employer has changed during the course of the year. A maximum of two changes are allowed. The resulting vectors of weekly hours and of weeks worked per month are then used to derive hourly wage rates from the reported earnings.

Since January 1997, the Labour Force Survey produces monthly information on wages. LFS distinguishes employees whose number of paid hours vary from week to week from other employees. Individuals whose hours vary are asked how many paid hours they usually work per week, on average. Other individuals are asked how many paid hours they work per week. The concept of hours excludes overtime. For each of the two groups of workers, hourly wages are calculated by dividing reported earnings by the appropriate number of weekly hours times the relevant number of weeks worked. Contrary to LMAS and SLID, LFS contains no question on the number of weeks worked per month. The LFS calculation of hourly wage rates implicitly assumes that all employees work four weeks per month.

Contrary to LMAS 1986-1990, SLID 1993-1995 and LFS 1997, the Survey of Work Arrangements conducted in November 1995 did not impute wages for those individuals who did not report their earnings. Roughly $25 \%$ of our SWA sample has no wage data. For this reason, caution will be required when interpreting the results on wages for 1995. To maximize the comparability of the wage data, we use LMAS 1986-1990, SLID 1993-1995 and LFS 1997 for our analysis of the trends in the employer size wage differential. 


\section{Appendix 2: Distribution of Employment by Establishment Size, 1986 - 1997}

Appendix 2 Table A2 - 1 presents the distribution of employment by establishment size. The data from various household surveys suggest that between 1986 and 1997, almost 40\% of employees worked in locations with less than 20 workers. In contrast, locations with 500 or more workers accounted for at most $10 \%$ of total employment in the commercial sector. No trend is evident for this period.

Previous work (Morissette, 1993), has shown that the distribution of employment by establishment size derived from SEPH (the Survey of Employment, Payroll and Hours) was markedly different from that obtained from LMAS. This may bias the wage differential between large and small establishments for a given year. However, the goal of this paper is not to evaluate the magnitude of the employer size wage differential but rather to examine whether or not this differential has changed over time. As long as the bias inherent in LMAS and other household surveys remains constant over time, we may be confident that the conclusions we draw about the trends in the employer size wage differential are valid.

To assess whether this is the case, we calculate the distribution of employment by plant size for the manufacturing sector using two different data sources (Appendix 2 Table A2 - 2): first, establishment data is taken from the Census of Manufactures and second, individual data is drawn from LMAS and SLID. The data spans the period 1986-1993. The Census of Manufactures shows that during this period, small plants accounted for 9-10\% of employment in manufacturing, compared to $24-26 \%$ in large plants. In contrast, the corresponding numbers from the household surveys are $16-17 \%$ and $17-21 \%$. While household surveys appear to overestimate (underestimate) the relative importance of small (large) plants, the extent to which they do so has not varied substantially over the period. We interpret this as evidence that household surveys may be used to investigate changes over time in the establishment size wage differential. 
Appendix 2 Table A2 - 1: Percentage distribution of employment by establishment size - Commercial sector, 1986-1997

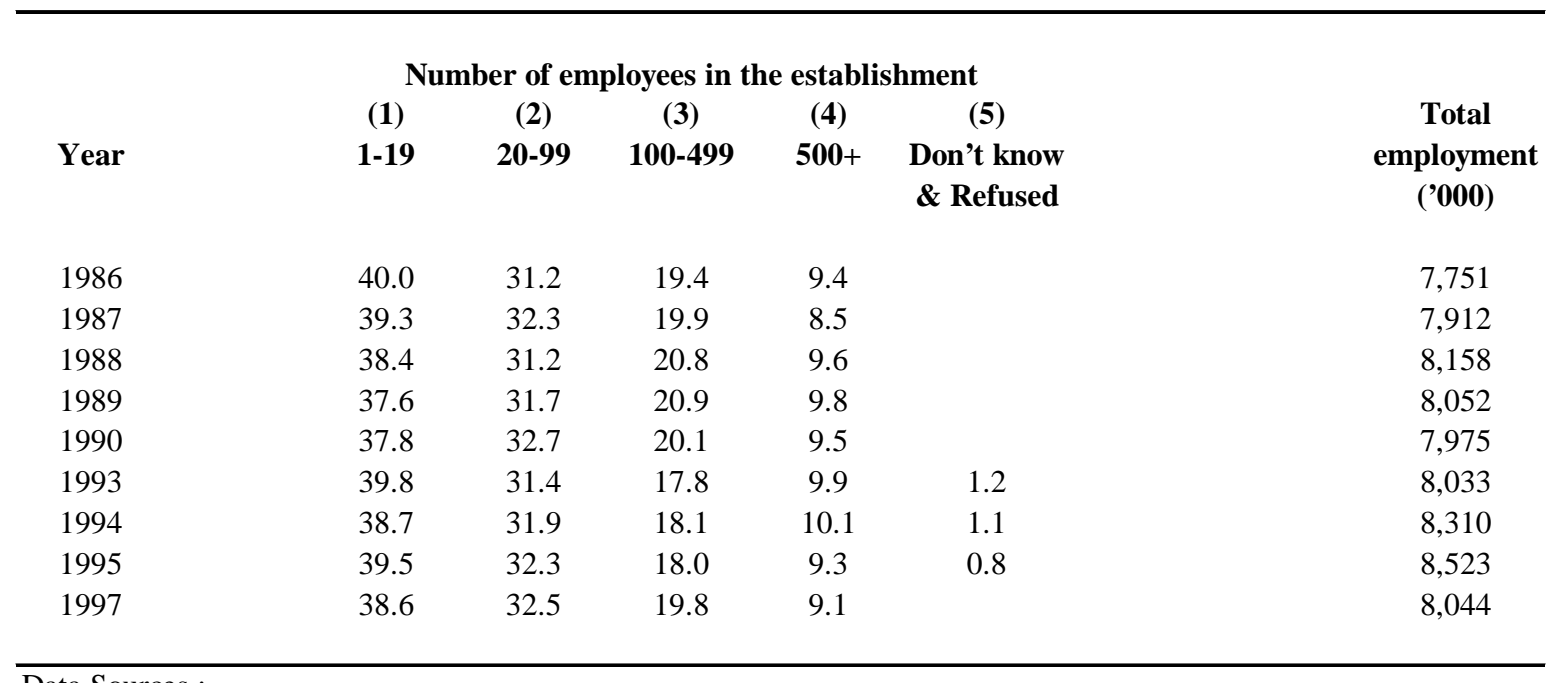

Data Sources :

- Labour Market Activity Survey of 1986-1990 and Survey of Labour and Income Dynamics of 1993-1995: jobs held in September by paid workers aged 17-64 who are employed in the commercial sector.

- Labour Force Survey of 1997 : main job held in September by paid workers aged 17-64 who are employed in the commercial sector. 
Appendix 2 Table A2-2 : Percentage distribution of employment by establishment size - manufacturing sector

I. Data from the Census of Manufactures

\section{Number of employees in the establishment}

$\begin{array}{cccc}(1) & (2) & (3) & (4) \\ 1-19 & 20-99 & 100-499 & 500+\end{array}$

1986

1987

1988

1989

1990

1991

1992

1993

\section{3}

26.5

26.5

27.7

29.1

29.4

30.0

28.5

28.6

26.3

26.2

25.7

25.2

24.4

24.5

24.2

23.5
Total employment ('000)

1,809

1,864

1,947

1,969

1,869

1,738

1,674

1,648

\section{Data from LMAS 1986-1990 and SLID 1993-1995*}

\begin{tabular}{|c|c|c|c|c|c|c|}
\hline & & ber of $\mathrm{e}$ & oyees in $\mathrm{t}$ & stablish & ient & \\
\hline & (1) & (2) & (3) & (4) & (5) & Total \\
\hline & $1-19$ & $20-99$ & $100-499$ & $500+$ & $\begin{array}{c}\text { Don't know } \\
\text { \& Refused }\end{array}$ & $\begin{array}{c}\text { employment } \\
\text { ('000) }\end{array}$ \\
\hline 1986 & 16.7 & 30.8 & 34.6 & 17.9 & & 2,043 \\
\hline 1987 & 16.1 & 31.5 & 35.7 & 16.8 & & 2,028 \\
\hline 1988 & 16.4 & 29.0 & 36.0 & 18.7 & & 2,109 \\
\hline 1989 & 16.5 & 29.3 & 35.4 & 18.8 & & 2,053 \\
\hline 1990 & 15.9 & 31.4 & 34.1 & 18.5 & & 1,994 \\
\hline 1993 & 17.1 & 28.9 & 32.3 & 20.7 & 0.9 & 1,879 \\
\hline 1994 & 16.0 & 29.5 & 30.8 & 22.0 & 1.7 & 1,942 \\
\hline 1995 & 15.8 & 31.9 & 29.7 & 22.2 & 0.5 & 1,981 \\
\hline
\end{tabular}

Data Sources :

* : - Labour Market Activity Survey of 1986-1990 and Survey of Labour and Income Dynamics of 1993-1995 : jobs held in September by paid workers aged 17-64 who are employed in the commercial sector. 


\section{Appendix 3: The Wage Gap Between Small and Large Establishments, 1986 - 1997}

Appendix 3 Table A3 - 1 presents the average hourly wage rates by establishment size for both men and women. Between 1986 and 1997, men in large establishments earned, on average 47\% more than men working in small establishments. The raw wage gap observed for women is higher - it averages $63 \%$ - and displays larger fluctuations but, as in the case for men, exhibits no trend. Appendix 3 Table A3 - 2 presents the results of the multivariate analysis by establishment size for each year. The net wage differentials between the smallest and largest categories trend neither upwards nor downwards for men and women.

Appendix 3 Table A3 - 3 presents the average hourly wage rates by establishment size group for the manufacturing sector. Between 1986 and 1997, workers in large manufacturing establishments earned, on average $44 \%$ more than other workers in small manufacturing establishments. Again, no trend is evident over this period.

We have shown that the location size wage differential does not appear to have changed since the mid-eighties. This is interesting given that the wage gap between small and large plants of the manufacturing sector rose substantially between the seventies and the mid-eighties in both Canada (Baldwin, 1996) and in the United States (Davis and Haltiwanger, 1991). Our results are consistent with those of Baldwin (1996) who show that most of the widening of the plant size wage differential occurred prior to 1986. 


\section{Men employed in full-time jobs}
(1)
(2)
(3)
(4)

(5)

Establishment size (number of employees)

Raw wage gap

\begin{tabular}{|c|c|c|c|c|c|}
\hline Year & $1-19$ & 20-99 & $100-499$ & $500+$ & {$[(4) /(1)]-1$} \\
\hline 1986 & 11.07 & 12.59 & 14.15 & 16.13 & $45.7 \%$ \\
\hline 1987 & 11.40 & 13.11 & 15.36 & 16.65 & $46.1 \%$ \\
\hline 1988 & 12.32 & 14.14 & 16.08 & 17.54 & $42.4 \%$ \\
\hline 1989 & 12.58 & 14.73 & 16.64 & 18.29 & $45.4 \%$ \\
\hline 1990 & 13.00 & 15.28 & 17.24 & 19.34 & $48.8 \%$ \\
\hline 1993 & 14.38 & 17.24 & 18.90 & 21.28 & $48.0 \%$ \\
\hline 1994 & 14.95 & 17.27 & 19.49 & 22.12 & $48.0 \%$ \\
\hline 1995 & 14.96 & 17.99 & 19.95 & 23.02 & $53.9 \%$ \\
\hline 1997 & 14.98 & 16.24 & 19.19 & 22.38 & $49.4 \%$ \\
\hline
\end{tabular}

\section{Women employed in full-time jobs}
(1)
(2)
(3)
(4)

(5)

Establishment size (number of employees)

Raw wage gap

\begin{tabular}{lccccc} 
Year & $\mathbf{1 - 1 9}$ & $\mathbf{2 0 - 9 9}$ & $\mathbf{1 0 0 - 4 9 9}$ & $\mathbf{5 0 0 +}$ & [(4) / (1)] - 1 \\
1986 & 7.26 & 8.86 & 9.82 & 11.84 & $63.1 \%$ \\
1987 & 7.92 & 9.43 & 10.39 & 12.57 & $58.7 \%$ \\
1988 & 8.57 & 10.23 & 11.02 & 14.06 & $64.1 \%$ \\
1989 & 9.08 & 10.36 & 11.71 & 14.05 & $54.7 \%$ \\
1990 & 9.27 & 10.81 & 12.18 & 14.73 & $58.9 \%$ \\
1993 & 10.81 & 12.43 & 14.12 & 18.43 & $70.5 \%$ \\
1994 & 11.12 & 12.79 & 14.77 & 18.69 & $68.1 \%$ \\
1995 & 11.04 & 13.18 & 14.50 & 18.67 & $69.1 \%$ \\
1997 & 11.25 & 12.96 & 13.99 & 18.27 & $62.4 \%$ \\
\hline
\end{tabular}

* For LMAS 1986-1990 and SLID 1993-1995, the sample consists of full-time jobs held in September by paid workers aged 17-64, who were not full-time students at any time during the year and who were employed in the commercial sector. For LFS 1997, the sample consists of main full-time jobs held in September by paid workers aged 17-64, who are not full-time students in September and who are employed in the commercial sector.

Source : Labour Market Activity Survey of 1986-1990

Survey of Labour and Income Dynamics of 1993-1995

Labour Force Survey of September 1997 


\begin{tabular}{|c|c|c|c|c|c|c|c|c|c|}
\hline & 1986 & 1987 & 1988 & 1989 & 1990 & 1993 & 1994 & 1995 & 1997 \\
\hline \multicolumn{10}{|l|}{ I. Men } \\
\hline \multicolumn{10}{|c|}{ No controls for occupation } \\
\hline E2 & 0.096 & 0.103 & 0.099 & 0.109 & 0.131 & 0.137 & 0.102 & 0.132 & 0.096 \\
\hline E3 & 0.185 & 0.210 & 0.186 & 0.190 & 0.197 & 0.219 & 0.186 & 0.202 & 0.205 \\
\hline E4 & 0.245 & 0.258 & 0.243 & 0.251 & 0.281 & 0.283 & 0.259 & 0.308 & 0.291 \\
\hline Adj. R squared & 0.3171 & 0.3192 & 0.3007 & 0.2978 & 0.3100 & 0.4091 & 0.3863 & 0.4271 & 0.3736 \\
\hline \multicolumn{10}{|c|}{ Controls for occupation included } \\
\hline E2 & 0.089 & 0.095 & 0.094 & 0.105 & 0.128 & 0.121 & 0.085 & 0.122 & 0.089 \\
\hline E3 & 0.170 & 0.188 & 0.174 & 0.172 & 0.174 & 0.184 & 0.141 & 0.178 & 0.174 \\
\hline $\mathrm{E} 4$ & 0.221 & 0.228 & 0.220 & 0.219 & 0.249 & 0.239 & 0.222 & 0.270 & 0.235 \\
\hline Adj. R squared & 0.3819 & 0.3784 & 0.3610 & 0.3532 & 0.3784 & 0.4963 & 0.4746 & 0.5107 & 0.5008 \\
\hline Sample size & 13,993 & 16,634 & 13,796 & 13,286 & 12,919 & 4,473 & 4,856 & 4,859 & 3,189 \\
\hline \multicolumn{10}{|l|}{ II. Women } \\
\hline \multicolumn{10}{|c|}{ No controls for occupation } \\
\hline E2 & 0.139 & 0.132 & 0.137 & 0.117 & 0.112 & 0.059 & 0.124 & 0.134 & 0.113 \\
\hline E3 & 0.219 & 0.191 & 0.198 & 0.216 & 0.174 & 0.190 & 0.218 & 0.204 & 0.166 \\
\hline E4 & 0.298 & 0.283 & 0.341 & 0.323 & 0.301 & 0.336 & 0.345 & 0.338 & 0.331 \\
\hline Adj. R squared & 0.3439 & 0.3232 & 0.2905 & 0.2738 & 0.3068 & 0.4468 & 0.4756 & 0.4660 & 0.4631 \\
\hline \multicolumn{10}{|c|}{ Controls for occupation included } \\
\hline E2 & 0.125 & 0.120 & 0.139 & 0.117 & 0.118 & 0.070 & 0.127 & 0.129 & 0.118 \\
\hline E3 & 0.196 & 0.176 & 0.195 & 0.194 & 0.173 & 0.176 & 0.204 & 0.194 & 0.191 \\
\hline $\mathrm{E} 4$ & 0.261 & 0.257 & 0.303 & 0.293 & 0.287 & 0.305 & 0.290 & 0.279 & 0.290 \\
\hline Adj. R squared & 0.4051 & 0.3816 & 0.3556 & 0.3426 & 0.3635 & 0.5220 & 0.5375 & 0.5370 & 0.5588 \\
\hline Sample size & 6,949 & 8,565 & 7,006 & 6,795 & 6,677 & 2,372 & 2,549 & 2,563 & 1,642 \\
\hline
\end{tabular}

* : not statistically significant at the $1 \%$ level (two-tailed test)

Note : E2 (E4) refers to establishments with 20-99 (500+) employees. Establishments with 1-19 employees are the reference group. The percentage wage differential between small and large establishments equals the antilog of the the regression coefficients shown in this table minus 1 . See Table 4 for data sources and sample definition.

- The dependent variable is the natural logarithm of hourly wages. The set of controls includes a constant, age, age squared, marital status, union status, industry (2-digit level), province and establishment size. Controls for occupation (2-digit level) are omitted in the first specification and included in the second. 


\section{All workers employed in full-time jobs}

(1) (2) (3) (4)

Firm size $\quad$ (number of employees)

(5)

\begin{tabular}{|c|c|c|c|c|c|}
\hline \multirow[b]{2}{*}{ Year } & \multirow{2}{*}{ Firm size } & \multicolumn{3}{|c|}{ (number of employees) } & \multirow[b]{2}{*}[(4)/(1)]{-1} \\
\hline & & 20-99 & 100-499 & 500+ & \\
\hline 1986 & 10.12 & 10.76 & 12.22 & 14.87 & $46.9 \%$ \\
\hline 1987 & 10.74 & 11.17 & 13.26 & 15.55 & $44.8 \%$ \\
\hline 1988 & 11.55 & 11.99 & 14.13 & 16.54 & $43.2 \%$ \\
\hline 1989 & 12.13 & 12.36 & 14.62 & 17.11 & $41.1 \%$ \\
\hline 1990 & 12.02 & 13.35 & 15.44 & 17.43 & $45.0 \%$ \\
\hline 1993 & 14.09 & 15.18 & 17.37 & 21.04 & $49.3 \%$ \\
\hline 1994 & 15.00 & 15.63 & 17.19 & 21.40 & $42.7 \%$ \\
\hline 1995 & 15.33 & 16.67 & 18.07 & 21.87 & $42.7 \%$ \\
\hline 1997 & 14.43 & 14.79 & 16.89 & 21.11 & $46.3 \%$ \\
\hline
\end{tabular}

* For LMAS 1986-1990 and SLID 1993-1995, the sample consists of full-time jobs held in September by paid workers aged 17-64, who were not full-time students at any time during the year and who were employed in the commercial sector. For LFS 1997, the sample consists of main full-time jobs held in September by paid workers aged 17-64, who are not full-time students in September and who are employed in the commercial sector.

Source : Labour Market Activity Survey of 1986-1990

Survey of Labour and Income Dynamics of 1993-1995

Labour Force Survey of September 1997 
Chart 1: Wage Gap Between Small and Large Firms, Full-Time Jobs, 1986-1997
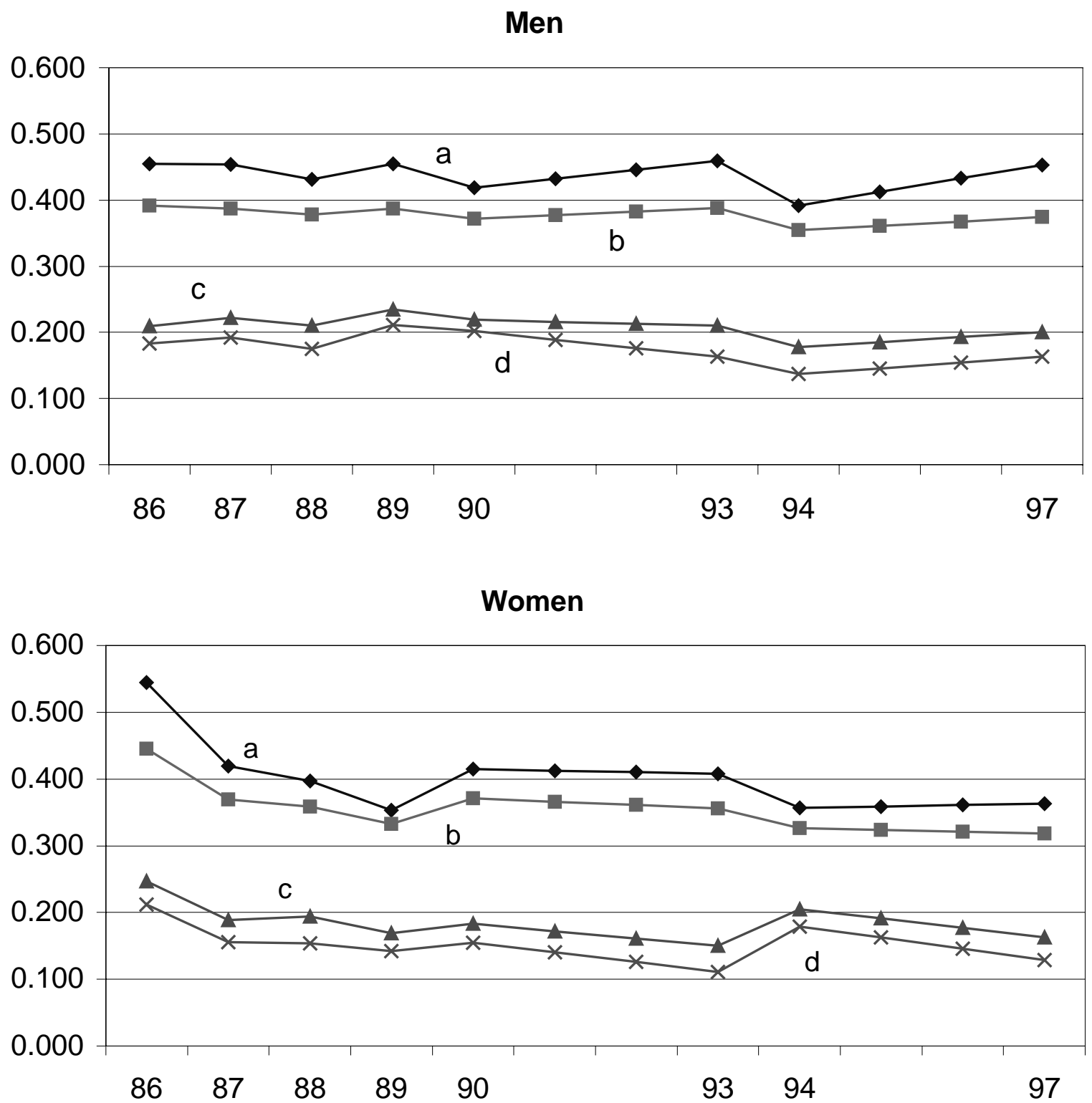

a: raw wage gap

b: raw log wage differential

c: log wage differential from Model 2

d: $\log$ wage differential from Model 1 
Chart 2: Wage Gap Between Small and Large Locations, Full-Time Jobs, 1986-1997

Men

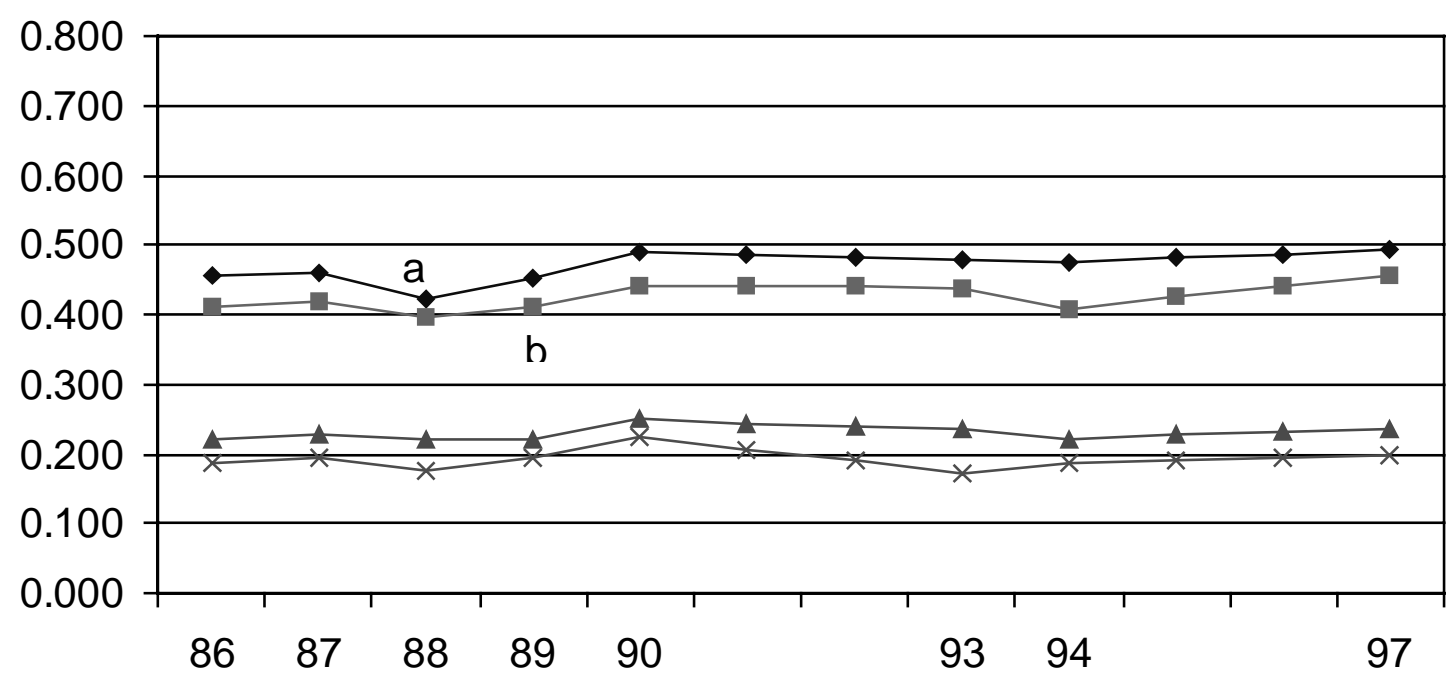

\section{Women}

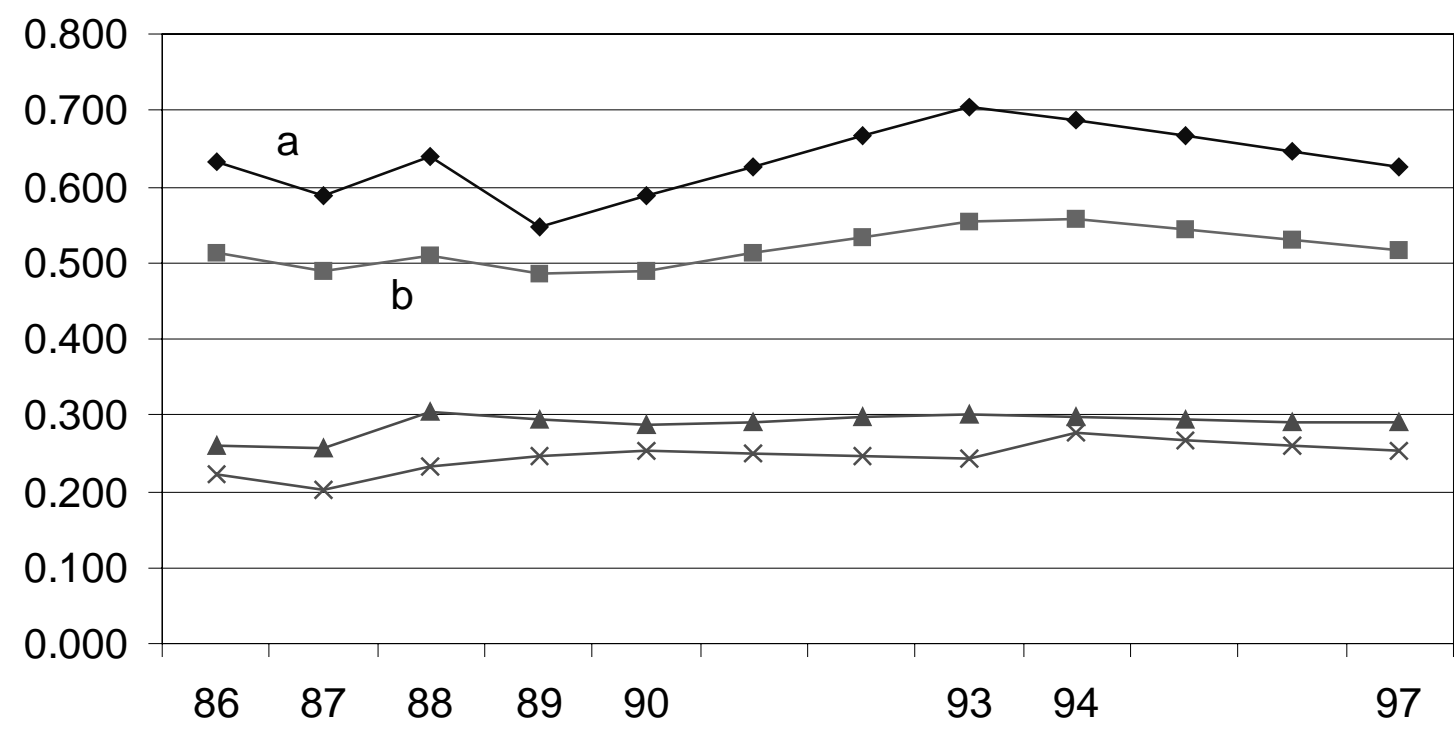

a: raw wage gap

b: raw log wage differential

c: $\log$ wage differential from Model 2

d: log wage differential from Model 1 


\section{Bibliography}

Akerlof, G.A. (1982) 'Labor Contracts as a Partial Gift Exchange.' Quarterly Journal of Economics 97: 543-69.

Baldwin, J.R. (1996) 'Were Small Producers the Engines of Growth in the Canadian Manufacturing Sector in the 1980s.' Statistics Canada, Analytical Studies Branch, Research paper no. 88.

Birch, D.L. (1981) 'Who Creates Jobs?’ Public Interest, 65: 3-14.

Blank, R. (1990) 'Are Part-Time Jobs Bad Jobs?' in A Future of Lousy Jobs? The Changing Structure of U.S. Wages, edited by Gary Burtless, Brookings Institution, 123-155.

Bulow, J. and L. Summers (1986) 'A Theory of Dual Labor Markets with Application to Industrial Policy, Discrimination and Keynesian Unemployment' Journal of Labor Economics, 4 (July 1986): 376-414.

Brown, C., and J. Medoff (1989) 'The Employer Size-Wage Effect' Journal of Political Economy, 97: 1027-59.

Davis, S.J. and J. Haltiwanger (1991) 'Wage Dispersion Between and Within U.S. Manufacturing Plants, 1963-1986’ Working Paper No. 3722, National Bureau of Economic Research.

Davis, S.J., J. Haltiwanger, and S. Schuh (1993) 'Small Business and Job Creation: Dissecting the Myth and Re-assessing the Facts' Working Paper No. 4492, National Bureau of Economic Research.

Evans, D.S. and L.S. Leighton (1989) 'Why Do Smaller Firms Pay Less?' Journal of Human Resources 24: 299-318.

Even and MacPherson (1996) 'Employer Size and Labor Turnover: The Role of Pensions' Industrial \& Labor Relations Review, 49, 4: 707-728.

Gower, D. (1993) 'The Impact of the 1990 Changes to the Education Questions on the Labour Force Survey', Staff Report, Labour and Household Surveys Analysis Division, Statistics Canada.

Hamermesh, D. (1996) 'Workdays, Workhours and Work Schedules: Evidence for the United States and Germany', W.E. Upjohn Institute for Employment Research, 154 p.

Idson, T.L. and D.J. Feaster (1990) 'A Selectivity Model of Employer-Size Wage Differentials' Journal of Labor Economics, 8: 99-122.

Kostiuk, P.F. (1990) 'Compensating Differentials for Shift Work' Journal of Political Economy 98: 1054-75.

Mayshar, J. and Y. Halevy (1997) 'Shiftwork' Journal of Labour Economics, Vol. 15 No. 1, pt 2: S198-S222. 
Morissette, R. (1992) 'Using LMAS to Estimate the Wage Differential Between Large and Small Firms in Canada' in Design and Analysis of Longitudinal Surveys: Symposium 92, Statistics Canada.

Morissette, R. (1993) 'Canadian Jobs and Firm Size: Do Smaller Firms Pay Less?' Canadian Journal of Economics 26: 159-74.

Morissette, R. (1993b) 'Getting a New Job in 1989-90 in Canada.' Research Paper No. 57, Analytical Studies Branch, Statistics Canada.

Oi, W.Y. (1983) 'Heterogeneous Firms and the Organization of Production' Economic Inquiry 21 (April 1983): 147-71.

Picot, G., J. Baldwin and R. Dupuy (1994) 'Have Small Firms Created a Disproportionate Share of New Jobs in Canada? A Re-assessment of the Facts'. Research Paper No. 71, Analytical Studies Branch, Statistics Canada.

Picot, G. and R. Dupuy (1996) 'Job Creation by Company Size Class: Concentration and Persistence of Job Gains and Losses in Canadian Companies' Research Paper No. 93, Analytical Studies Branch, Statistics Canada.

Picot, G. and Z. Lin (1997) 'Have Permanent Layoffs Risen in the 1990s?' Canadian Economic Observer, (September 1997), Cat. No. 11-010-XPB, 3.1-3.18, Statistics Canada.

Salop, S.C. (1979) 'A Model of the Natural Rate of Unemployment' American Economic Review 69: $117-25$.

Schmidt, C.M. and K.F. Zimmerman (1991) 'Work Characteristics, Firm Size and Wages' Review of Economics and Statistics 73: 705-710.

Shapiro, V., and J.E. Stiglitz (1984) 'Equilibrium Unemployment As a Worker Discipline Device' American Economic Review 74: 433-44.

Weiss, Y. (1996) 'Synchronization of Work Schedules; International Economic Review 37, p. 157179. 